Article

\title{
Synthesis and Characterization of Some New Coumarins with In Vitro Antitumor and Antioxidant Activity and High Protective Effects against DNA Damage
}

\author{
Mounir A. I. Salem ${ }^{1, \dagger}$, Magda I. Marzouk ${ }^{1, *, \dagger}$ and Azza M. El-Kazak ${ }^{2, \dagger}$ \\ 1 Synthetic Organic Chemistry Laboratory, Chemistry Department, Faculty of Science, Ain Shams University, \\ Abassia, Cairo 11566, Egypt; salemmai1947@yahoo.com \\ 2 Faculty of Education; Ain Shams University, Roxy, Cairo 11711, Egypt; az_azelkazak@hotmail.com \\ * Correspondence: magda_marzouk@sci.asu.edu.eg; Tel.: +20-2-0122-330-9974 \\ + All the authors contributed equally to this work.
}

Academic Editor: Pascal Richomme

Received: 23 December 2015 ; Accepted: 17 February 2016 ; Published: 22 February 2016

\begin{abstract}
Coumarins are naturally occurring oxygen heterocyclic compounds having multifarious medicinal properties, hence used as lead compounds for designing new potent analogs. The chromene butenoic acid 3 and the benzochromene butenoic acid 4 which are derived from the reaction of glyoxalic acid with 3-acetylcoumarin and 3-acetylbenzocoumarin, respectively, were reacted with different nitrogen and carbon nucleophiles to give new heterocyclic compounds. The structures of the prepared compounds were elucidated by IR, ${ }^{1} \mathrm{H}-\mathrm{NMR}$, and mass spectroscopy. Some of the newly prepared compounds were tested in vitro against a panel of four human tumor cell lines namely; hepatocellular carcinoma (liver) HepG2, colon cancer HCT-116, human prostate cancer PC3, and mammary gland breast MCF-7. Also they were tested as antioxidants. Almost all of the tested compounds showed satisfactory activity.
\end{abstract}

Keywords: functionalized coumarin; antitumor activity; antioxidant activity

\section{Introduction}

Coumarins are an important class of compounds of both natural and synthetic origin. Many compounds which contain the coumarin moiety exhibit useful and diverse pharmaceutical and biological activities, often depending on the substituents they bear in the parent benzopyran moiety [1,2] and, there has been a growing interest in their synthesis [3]. Some of these coumarin derivatives have been found useful in photochemotherapy, antitumor [4], anti-HIV therapy [5,6], as CNS-stimulants [7], antibacterial [8-10], anticoagulants [11-13], antifungal [14,15], antioxidant [16] agents and as dyes [17]. Natural, semi-synthetic and synthetic coumarins are useful substances in drug research [18]. Coumarins can be used not only to treat cancer, but to treat the side effects caused by radiotherapy $[19,20]$. Coumarin derivatives can possess not only cytostatic, but cytotoxic properties as well [21], as they can inhibit growth in human cancer cell lines [22] such as A549 (lung), ACHN (renal), H727 (lung), MCF7 (breast) and HL-60 (leukemia) and in some clinical trials they exhibited anti-proliferative activity in prostate cancer [23] malignant melanoma [24] and renal cell carcinoma [25]. Coumarin itself also exhibited cytotoxic effects against Hep2 cells (human epithelial type 2) in a dose dependent manner and showed some typical characteristics of apoptosis with loss of membrane microvilli, cytoplasmic hypervacualization and nuclear fragmentation [26]. 
The hormone oestrogen plays the crucial role in the development of the breast cancer, the most frequent malignant disease in women. Therefore many therapies are designed to block its activity [27]. Cinnamoyl-coumarin derivatives were especially effective in oestrogen-dependent cancers, such as breast (MCF7) and ovarian (OVCAR) cancer cell lines. These compounds are selective nonsteroidal inhibitors of $14 \beta$-hydroxysteroid dehydrogenase type 1 , an enzyme that catalyzes NADPH-dependent reduction of the weak oestrogen, oestrone, into the most potent oestrogen, oestradiol [28]. Seidel et al. [29] synthesized a series of coumarin derivatives which carry $\alpha, \beta$-(monoor bis)-unsaturated ketones at the $\mathrm{C} 3$ or $\mathrm{C} 4$ position such as compound I (Figure 1) which strongly inhibits proliferation in the chronic myeloid leukemia K-562 and histiocytic lymphoma U-937 cell lines. This compound also inhibited the activity of histone deacetylase (HDAC), an enzyme crucial in cancer development.
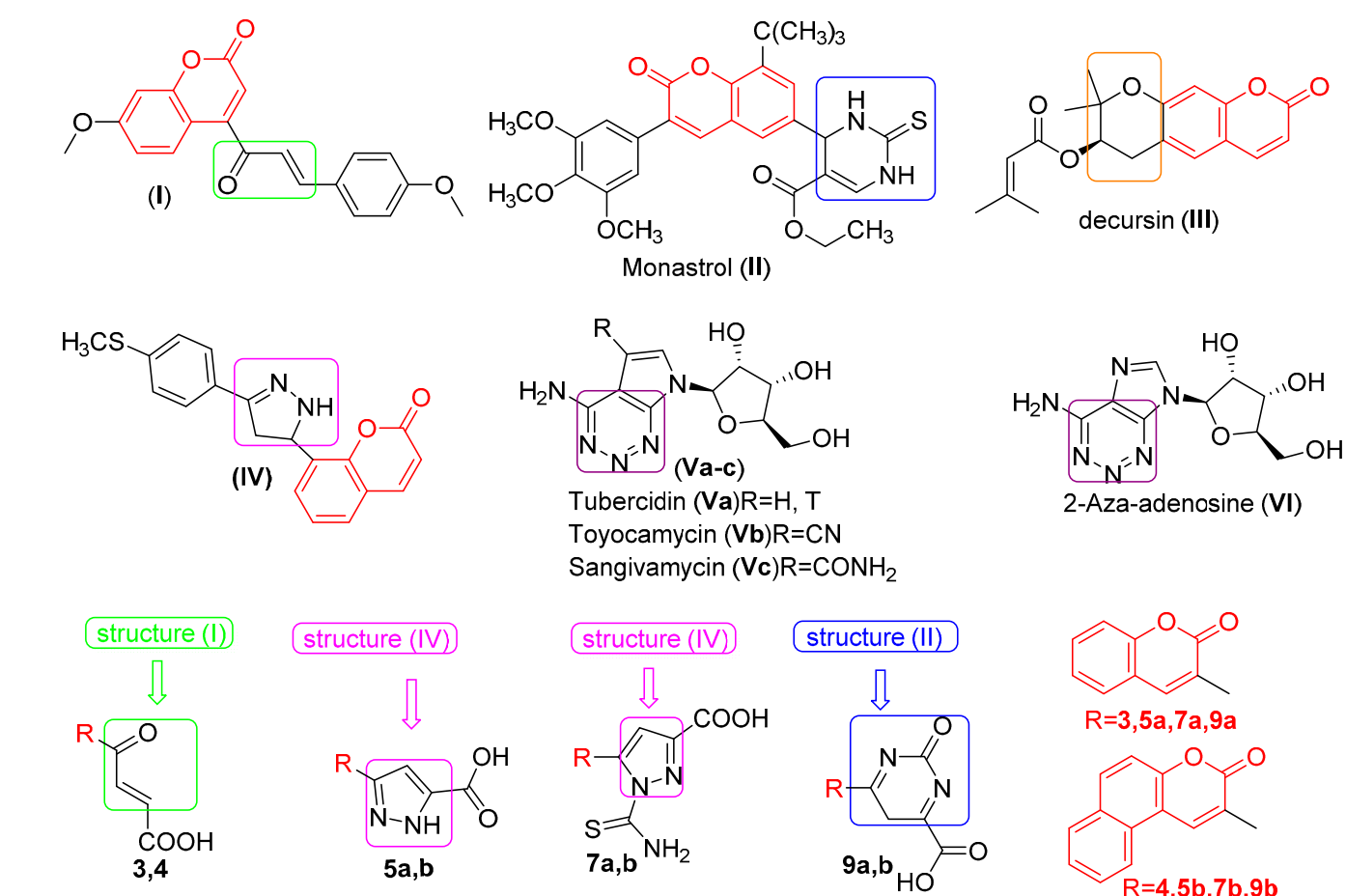

Sangivamycin $(\mathbf{V c}) \mathrm{R}=\mathrm{CONH}_{2}$
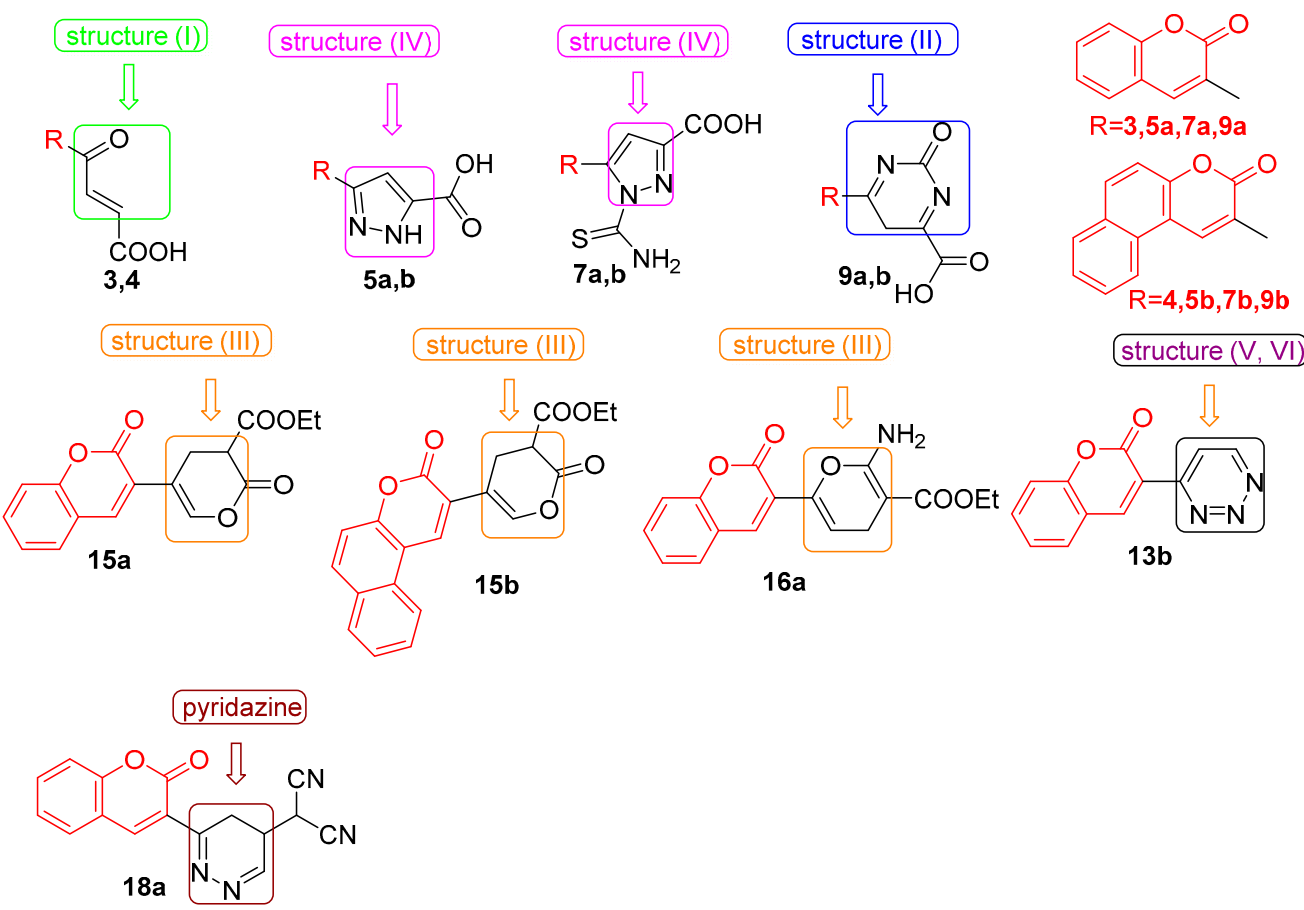

Figure 1. Structure of some anticancer derivatives (I-VI) and some of the designed target compounds $3,4,5 a, b, 7 a, b, 9 a, b, 13 b, 15 a, b, 16 a$ and $18 a$. 
Sashidhara et al. [27] developed new hybrid coumarin-monastrol molecules such as compound II (Figure 1) which showed the most potent selective activity against breast cancer cell lines MCF-7 and MDA-MB-231. This compound induced caspase-3 activation and apoptosis and caused arrest of MCF-7 cell cycle at G1 phase.

From Korean Angelica gigas root Kim et al. [30] isolated pyranocoumarin decursin III (Figure 1), which inhibited proliferation in bladder cancer 235J cells and also in colon cancer HCT-1116 cells. Decursin induced apoptosis in both cancer cell lines through expression of Bax protein and reduced Bcl-2 protein levels. Amin et al. [31] synthesized coumarins IV attached to pyrazoline rings (Figure 1) that have anticancer activity against the HepG2 cell line.

Drugs containing 1,2,3-triazine rings [32] originated from natural and synthetic sources are exemplified by tubercidin (Va), toyocamycin (Vb) and sangivamycin (Vc) (Figure 1), which have significant pharmacological activities. Tubercidin (Va) and its 5-substituted derivatives inhibit both DNA and RNA viruses at the concentrations that inhibit DNA, RNA and protein synthesis in mice and human cell lines. Toyocamycin $(\mathbf{V b})$ is a known antineoplastic antibiotic with specific antitumor activity. Sangivamycin (Vc) is active against L1210 leukemia, P338 leukemia and Lewis lung carcinoma and under clinical trials against colon cancer, gall bladder cancer and acute myelogenous leukemia in humans. 2-Azaadenosine VI (Figure 1) exhibits five times greater cytotoxicity than 8-azapurine against human epidermis carcinoma cells in vitro.

In continuation of our previous investigations [33-37], some heterocyclic compounds bearing the coumarin moiety were utilized herein for the synthesis of valuable heterocyclic ring systems having satisfactory antitumor and antioxidant activities.

\section{Results and Discussion}

\subsection{Chemistry}

In the present investigation we report the syntheses of some new coumarin derivatives having antitumor and antioxidant activities. 4-Oxo-4-(2-oxo-2H-chromen-3-yl)but-2-enoic acid (3) was synthesized by Tolstoluzhsky et al. [38] using glyoxalic acid and acetic anhydride in the presence of ytterbium triflate as a catalyst under microwave conditions. Herein we synthesized the target compounds 3 and 4 by the reaction of 3-acetyl-2H-chromen-2-one (1a) and 2-acetyl-3H-benzo[f]chromen-3-one (1b) with glyoxalic acid (2) in acetic acid/ $\mathrm{HCl}$ to afford 4-oxo-4-(2-oxo-2H-chromen3-yl)but-2-enoic acid (3) and 4-oxo-4-(3-oxo-3H-benzo[f]chromen-2-yl)but-2-enoic acid (4), respectively (Scheme 1). The IR spectra of compounds 3 and 4 showed characteristic absorption bands at 3446, 3476 $\mathrm{cm}^{-1}$ attributable to $\mathrm{OH}$ and also in the range 1730-1656 and 1742-1642 $\mathrm{cm}^{-1}$ attributable to $\mathrm{C}=\mathrm{O}$, respectively. ${ }^{1} \mathrm{H}-\mathrm{NMR}$ spectra of compounds 3 and 4 showed exchangeable signals at $\delta 12.51,9.40$ ppm, respectively, assigned to the $\mathrm{OH}$ protons. The mass spectra of compounds 3 and 4 showed the molecular ion peak at $m / z 244$ and a $[\mathrm{M}+2]^{+}$peak at $m / z 296$, respectively which coincide with the molecular weights supporting the proposed identity of the structures.

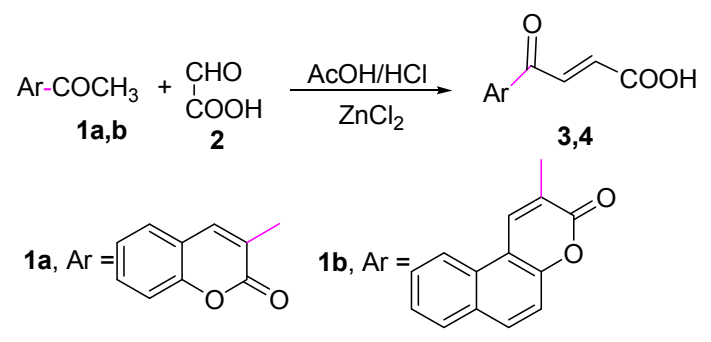

Scheme 1. Synthesis of compounds 3 and 4.

In principle, a nucleophile might be expected to attack a coumarin substrate at any of the electrophilic centers, C-1' (I) C-2 (II), C-3' (III) or C-4 (IV) as illustrated in Figure 2. 


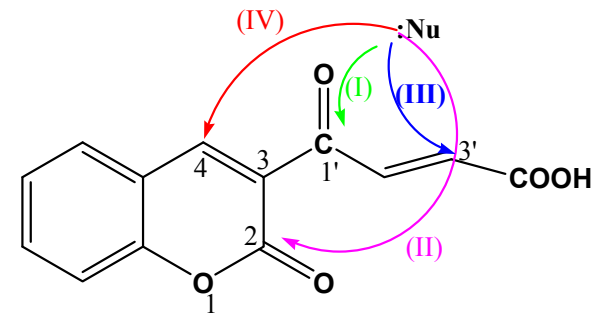

Figure 2. Possible sites of nucleophile attack on coumarin derivatives.

The reactions of compounds 3 and 4 with various nitrogen nucleophiles have been shown to proceed with a high degree of regioselective at the exocyclic acrylic center at C-3' followed by exo-trig ring closure to afford the substituted coumarin products (Scheme 2). Aroylacrylic acid derivatives can be used in a wide range of the addition reaction. The strong electron-attracting power of the aryl carbonyl group enhances the reactivity of the adjacent double bond-function and promotes the nucleophilic addition at this center. Simultaneous or subsequent cyclization of adducts gives access to various 5- or 6-membered cyclic structures. All the structures were proved by spectroscopic studies.

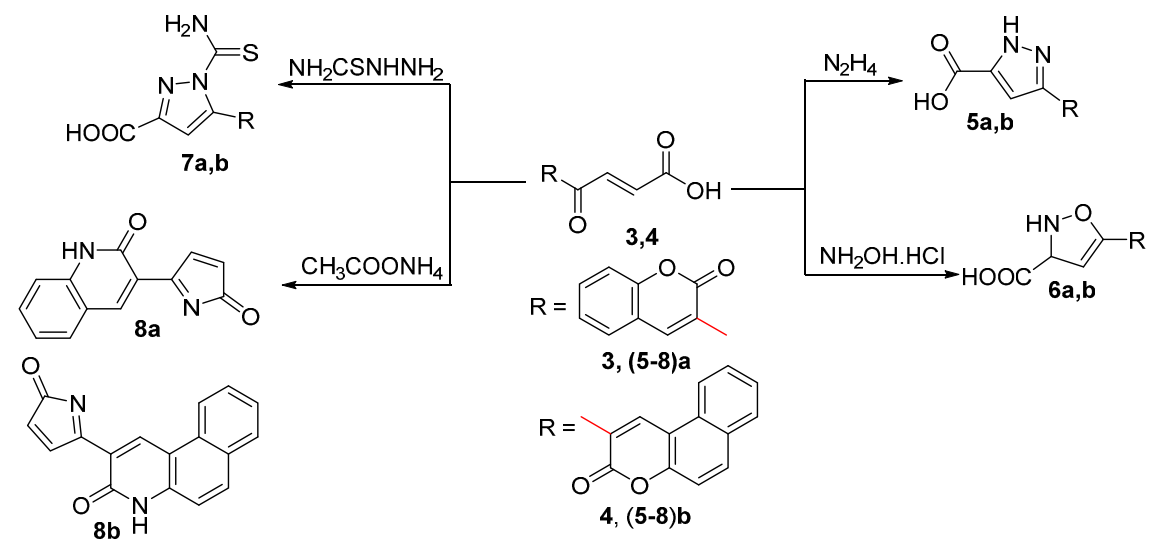

Scheme 2. Synthesis of compounds (5-8)a,b.

Compounds 3 and 4 were reacted with hydrazine hydrate [39] to yield the pyrazolecarboxylic acid derivatives $\mathbf{5} \mathbf{a}$ and $\mathbf{5 b}$, respectively, via aza Michael addition followed by cyclization (Scheme 2 ). The spectroscopic data are consistent with the proposed structures. The IR spectra of compounds $\mathbf{5 a}$ and $\mathbf{5 b}$ showed bands for acidic $\mathrm{OH}$ and $\mathrm{NH}$ protons at $3440,3217,3400$ and $3283 \mathrm{~cm}^{-1}$ respectively. The ${ }^{1} \mathrm{H}-\mathrm{NMR}$ spectra showed the appearance of $\mathrm{OH}$ protons at $\delta 11.03$ and $12.82 \mathrm{ppm}$ and $\mathrm{NH}$ protons at 7.01 and 6.99 ppm for compounds $5 \mathbf{a}$ and $\mathbf{5 b}$ respectively indicated the presence of the carboxylic and the $\mathrm{NH}$ groups.

Similarly, treatment of compounds 3 and 4 with hydroxylamine hydrochloride in pyridine [39] afforded compounds $\mathbf{6 a}$ and $\mathbf{6 b}$. The structures of compounds $\mathbf{6 a}$ and $\mathbf{6 b}$ were deduced from their elemental analysis and spectral data. The IR spectra showed bands for $\mathrm{OH}, \mathrm{NH}$ and $\mathrm{C}=\mathrm{O}$ at 3393, 3380, $3204,3128,1720,1728,1710$ and $1718 \mathrm{~cm}^{-1}$ respectively. The ${ }^{1} \mathrm{H}-\mathrm{NMR}$ spectra showed the presence of exchangeable $\mathrm{OH}$ and $\mathrm{NH}$ protons at $\delta 11.90,11.52,10.10$ and $6.93 \mathrm{ppm}$ respectively, beside signals for aromatic and $=\mathrm{CH}$ protons ( $c f$. Experimental Section).

Compounds 3 and 4 were also reacted with thiosemicarbazide [40] to yield compounds $7 \mathbf{a}$ and $\mathbf{7 b}$. The structures of compounds $7 \mathbf{a}$ and $\mathbf{7 b}$ were deduced by spectroscopic data. The IR spectra showed bands for $\mathrm{OH}, \mathrm{NH}$ and $\mathrm{C}=\mathrm{O}$ at 3455, 3382, 3397, 1711, 1712, 1647 and $1653 \mathrm{~cm}^{-1}$, respectively. The ${ }^{1} \mathrm{H}-\mathrm{NMR}$ spectra showed the presence of exchangeable $\mathrm{OH}, \mathrm{NH}_{2}$ at $\delta 12.26,12.0,5.71$ and $6.48 \mathrm{ppm}$, respectively, beside signals for aromatic and $=\mathrm{CH}$ protons ( $c f$. Experimental Section). 
Compounds $\mathbf{8 a}$ and $\mathbf{8 b}$ were formed when a mixture of compounds $\mathbf{3}$ and/or $\mathbf{4}$ was fused with ammonium acetate for $3 \mathrm{~h}$ in the absence of solvent [41]. Proof of the structures of compounds $\mathbf{8 a}$ and $\mathbf{8 b}$ were based on spectral data. The IR spectra showed bands attributed to NH, and $\mathrm{C}=\mathrm{O}$ in the range 3181-3385 and 1642-1713 respectively. Also the ${ }^{1} \mathrm{H}-\mathrm{NMR}$ showed signals at $\delta 9.57$ and 9.71 ppm for $\mathrm{NH}$ protons beside signals in the range of 7.95-8.16, 6.97-8.06 ppm attributed to coumarin, aromatic and $\mathrm{HC}=\mathrm{CH}$ protons, respectively. The ammonium acetate was reacted with the carboxylic acid group followed by ring closure, and also with the coumarin ring to give the oxopyrrolylquinolinone and the oxopyrrolylbenzoquinolinone derivatives $\mathbf{8 a}$ and $\mathbf{8 b}$, respectively.

Furthermore, the reaction of compounds 3 and 4 with urea, thiourea [40] and guanidine hydrochloride in DMF afforded products whose spectra (IR, ${ }^{1} \mathrm{H}-\mathrm{NMR}$ and MS) and elemental analyses data are consistent with compounds (9-11)a,b rather than compounds $\left(\mathbf{9}^{\prime}-\mathbf{1 1}\right) \mathbf{a}, \mathbf{b}$ (Scheme 3). The reaction took place via addition of the nitrogen nucleophile on the $\alpha$-carbon atom followed by exo-trig ring closure on the ketonic carbonyl carbon atom and dehydrogenation to give compounds (9-11)a,b. The structures of compounds (9-11)a,b were confirmed by spectroscopic data. The other products $\left(\mathbf{9}^{\prime}-\mathbf{1 1}\right) \mathbf{a}, \mathbf{b}$ were discounted on the basis of the spectral data. The IR spectra of compounds (9-11)a,b showed bands for $\mathrm{OH}$ and $\mathrm{C}=\mathrm{O}$ in the range $3403-3455$ and $1642-1653 \mathrm{~cm}^{-1}$ respectively. The ${ }^{1} \mathrm{H}-\mathrm{NMR}$ spectra showed the appearance of $\mathrm{CH}_{2}$ and $\mathrm{OH}$ protons in the range 1.20-1.23 and 9.78-11.23 ppm respectively for compounds (9-11)a,b which indicated the presence of the methylene and the carboxylic groups. The mass spectrum of compound 9a showed the molecular ion peak at $m / z 284(14.42 \%)$ which is in a good agreement with the molecular formula $\mathrm{C}_{14} \mathrm{H}_{8} \mathrm{~N}_{2} \mathrm{O}_{5}$. Compound 10a failed to react with benzaldehyde in the presence of a mixture of acetic acid, acetic anhydride and zinc chloride, which is a good evidence for the existence of compound $10 \mathrm{a}$ and not $10^{\prime} \mathbf{a}$.

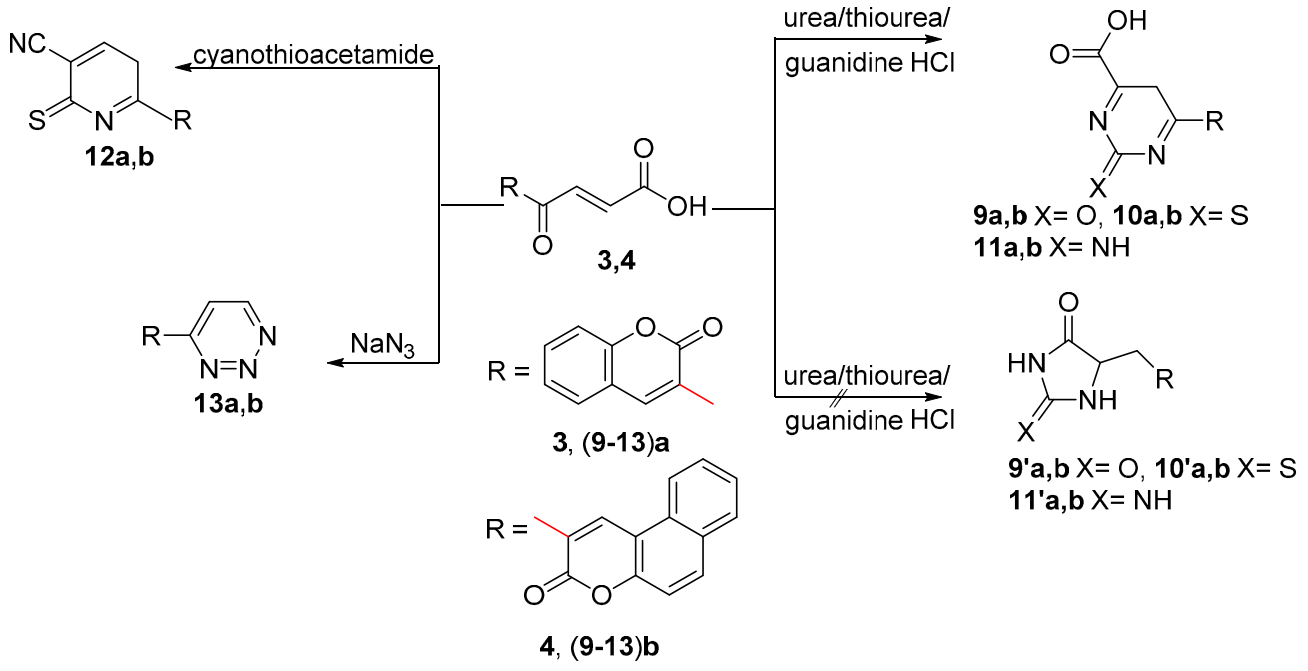

Scheme 3. Synthesis of compounds (9-13)a,b.

Cyanothioacetamide reacted with compounds 3 and 4 to give compounds 12a,b. Cyanothioacetamide [42] has three nucleophile sites: the methylene carbon, the amino group and the sulfur atom. On the whole, under cyclocondensation or cycloaddition conditions, cyanothio-acetamide acts as a $\mathrm{C}, \mathrm{N}-, \mathrm{C}, \mathrm{S}-$ or $\mathrm{S}, \mathrm{N}$ - binucleophile. In this case the reaction occurred via Michael addition reaction followed by ring closure, elimination of water and hydrogen molecules to give compounds 12a and 12b. The IR spectra showed bands attributable to $C \equiv N$ and $C=O$ groups at 2209, 2207, 1713 and $1705 \mathrm{~cm}^{-1}$ respectively, with the absence of bands attributable to $\mathrm{OH}$ and $\mathrm{NH}$ groups. The ${ }^{1} \mathrm{H}-\mathrm{NMR}$ spectra showed the presence of signals for aromatic, $=\mathrm{CH}$, coumarinic hydrogen, and $\mathrm{CH}_{2}$ protons at 6.22-7.94, 6.81-7.95, 1.72 and 1.20 ppm, respectively. The mass spectra of compounds 12a 
and $\mathbf{1 2 b}$ showed the molecular ion peak at $m / z 280$ and a $[\mathrm{M}+2]^{+}$ion at $m / z 332$, respectively, which agree well with the suggested structures.

On the other hand, sodium azide reacted with compounds 3 and 4 to yield the triazine derivatives 13a and 13b. The reaction occurred via addition reaction on the carbon double bond followed by ring closure, elimination of water molecule and decarboxylation to give the stable compounds 13a and $\mathbf{1 3 b}$. The structures of compounds $13 \mathrm{a}$ and $\mathbf{1 3 b}$ were confirmed based on spectral data. The IR showed bands for $\mathrm{C}=\mathrm{O}$ and $\mathrm{C}=\mathrm{N}$ at 1718,1707 and $1631,1624 \mathrm{~cm}^{-1}$, respectively and the absence of bands corresponding to $\mathrm{OH}$ and $\mathrm{NH}$ groups. The ${ }^{1} \mathrm{H}-\mathrm{NMR}$ spectra showed the absence of signals corresponding to $\mathrm{NH}$ and $\mathrm{OH}$ protons, and showed signals for coumarin, aromatic and two $=\mathrm{CH}$ protons in the range $8.89-6.42 \mathrm{ppm}$.

Lawesson's reagent is a powerful, mild, and versatile thiation agent that efficiently converts oxygen functionalities into their thio-analogs. This reagent has been used for the cyclization of compounds containing at least two oxygen functionalities [43] Lawesson's reagent acts as a sulfurizing agent as well as dehydrating agent. Compounds $\mathbf{3}$ and $\mathbf{4}$ were refluxed with Lawesson's reagent in acetonitrile to give compounds $14 \mathbf{a}$ and $\mathbf{1 4 b}$ (Scheme 4).

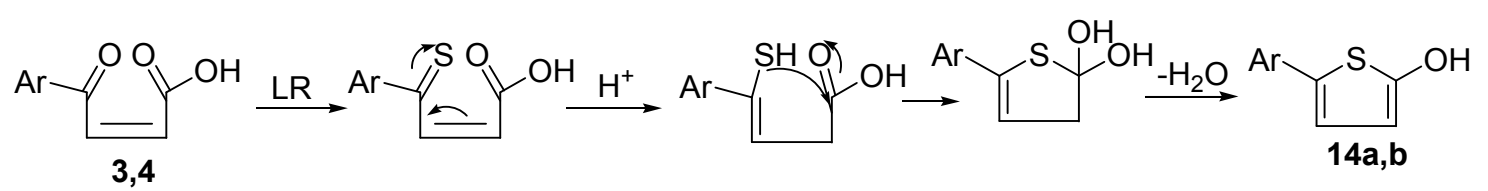

Scheme 4. Mechanistic route of compounds 14a,b.

The reaction seems to produce like Paal-Knorr synthesis mechanism to produce the thiophene ring (Scheme 4). Proof of the structures of compounds $14 \mathbf{a}$ and $\mathbf{1 4 b}$ were based on spectral data. The IR spectra showed bands attributed to $\mathrm{OH}$ and $\mathrm{C}=\mathrm{O}$ at 3557,3428 and $1724 \mathrm{~cm}^{-1}$, respectively. The ${ }^{1} \mathrm{H}-\mathrm{NMR}$ showed signals for aromatic, coumarin proton, two $=\mathrm{CH}$ and $\mathrm{OH}$ protons at 7.61-7.54, $7.37-8.64,6.91,6.96,7.14$ and $6.20 \mathrm{ppm}$ respectively. The mass spectra of compounds 14a and 14b showed the molecular ion peaks at $m / z 261$ and 310, respectively, which coincide with their molecular weights.

The present study was extended to investigate the chemical behavior of compounds 3 and 4 towards some acyclic carbon nucleophiles containing an active methylene group between two carbonyl groups (Scheme 5). There have been reports on Michael reactions catalyzed by $\mathrm{K}_{2} \mathrm{CO}_{3}$ under phase transfer catalysis [44]. To some extent these mild conditions can minimize the reversibility of the Michael addition reaction [45] and other side reactions, thus improved yields can be achieved. Therefore, boiling [39] compounds 3 and 4 with diethyl malonate and/or ethyl cyanoacetate under PTC reaction conditions in the presence of $\mathrm{K}_{2} \mathrm{CO}_{3}$ and tetrabutyl- $n$-ammonium bromide afforded compounds $(\mathbf{1 5}, \mathbf{1 6}) \mathbf{a}, \mathbf{b}$, respectively. The pyranone derivatives $(\mathbf{1 5}, \mathbf{1 6}) \mathbf{a}, \mathbf{b}$ were formed via Michael addition reaction of the carbanion at the exo-double bond followed by cyclization and decarboxylation. The structures of compounds $(\mathbf{1 5 , 1 6 )} \mathbf{a}, \mathbf{b}$ were elucidated by spectroscopic data. The IR of compounds 15a and $15 \mathbf{b}$ showed bands at $1715,1716 \mathrm{~cm}^{-1}$ for ester groups, respectively. The ${ }^{1} \mathrm{H}-\mathrm{NMR}$ of compounds 15a and 15b showed triplet signals attributed to $\mathrm{CH}_{3}$ at $0.93 \mathrm{ppm}$ and quartet signal for $\mathrm{OCH}_{2}$ at 3.16-3.18 and 3.12-3.18 ppm, respectively beside signals for $\mathrm{CH}_{2}, \mathrm{CH},=\mathrm{CH}$ and aromatic protons in the range 1.22-1.35, 1.50-1.62, 6.50-8.16 ppm, respectively. Also the spectra showed a signal for the coumarin proton at 8.59 and $8.53 \mathrm{ppm}$, respectively. The IR of compounds $16 \mathbf{a}$ and $16 \mathbf{b}$ showed bands at 3418, 3228, 3409 and $3242 \mathrm{~cm}^{-1}$ attributed to $\mathrm{NH}_{2}$ and also bands at $1712 \mathrm{~cm}^{-1}$ for $\mathrm{C}=\mathrm{O}$ group. The ${ }^{1} \mathrm{H}-\mathrm{NMR}$ of compounds $16 \mathbf{a}$ and $\mathbf{1 6 b}$ showed signals for $\mathrm{CH}_{3}, \mathrm{CH}_{2}, \mathrm{OCH}_{2}, \mathrm{NH}_{2},=\mathrm{CH}$, aromatic and coumarin protons. 


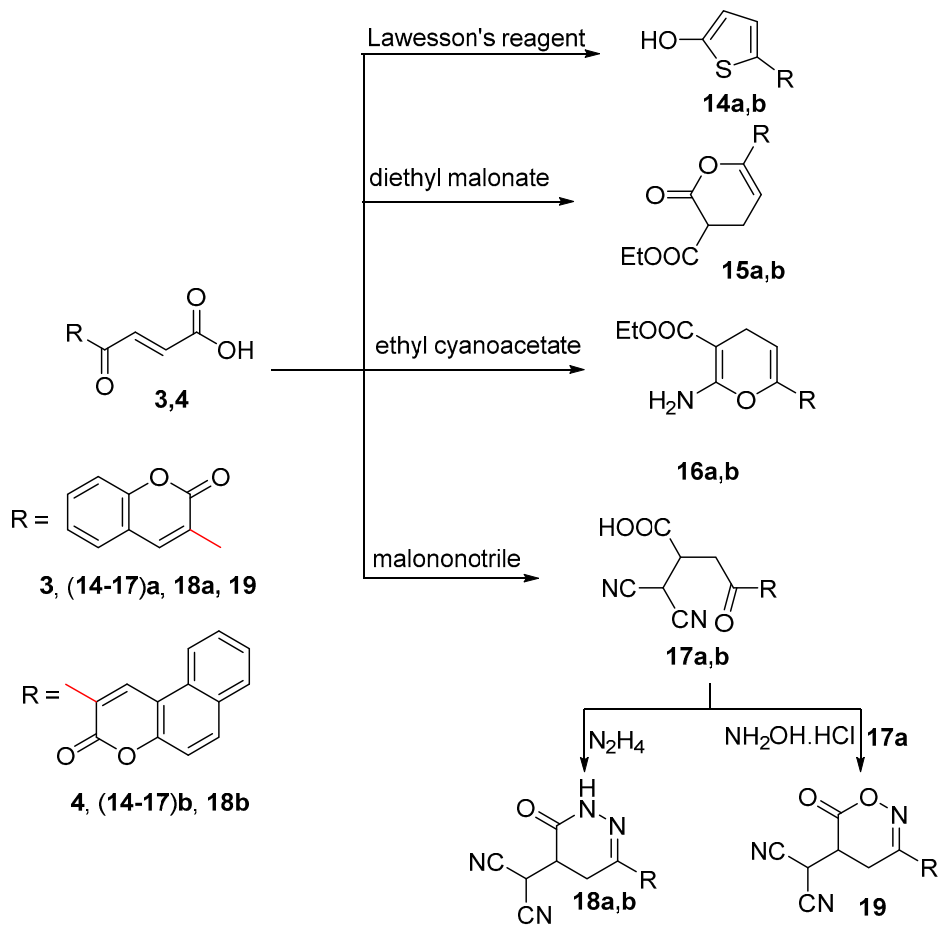

Scheme 5. Synthesis of compounds 14-19.

Meanwhile the reaction of compounds 3 and 4 with malononitrile [46] under the same conditions afforded the open structures $17 \mathbf{a}$ and $17 \mathbf{b}$, respectively. The structures of compounds $17 \mathbf{a}$ and $17 \mathbf{b}$ were elucidated by spectroscopic data. The IR spectra showed bands for $\mathrm{OH}, \mathrm{C} \equiv \mathrm{N}$ and $\mathrm{C}=\mathrm{O}$ at 3434,2209 , 2210, 1646 (broad) and 1632 (broad) $\mathrm{cm}^{-1}$, respectively. Also the ${ }^{1} \mathrm{H}-\mathrm{NMR}$ spectra showed signals for $\mathrm{OH}$ protons at 12.22 and $12.56 \mathrm{ppm}$, respectively, in addition to signals attributed to $\mathrm{CH}, \mathrm{CH}_{2}$, aromatic and coumarin protons. The structures of compounds $17 \mathrm{a}$ and $\mathbf{1 7} \mathrm{b}$ were deduced chemically by their reaction with hydrazine hydrate [46] and also the reaction of $\mathbf{1 7 a}$ with hydroxylamine hydrochloride to give compounds $18 \mathrm{a}, \mathbf{1 8 b}$ and 19 , respectively. The reaction was proceeded via condensation reaction of the $\mathrm{NH}_{2}$ group with the ketonic group followed by 6-exo-trig cyclization. The structures of compounds 18a, 18b and 19 were proved by spectroscopic tools. The IR spectra showed bands in the range $2207-2211,1627-1713 \mathrm{~cm}^{-1}$ attributable to $C \equiv N$ and $C=O$ groups, respectively, in addition to bands at 3362 and $3399 \mathrm{~cm}^{-1}$ attributable to $\mathrm{NH}$ for compounds 18a and $\mathbf{1 8 b}$, respectively. The ${ }^{1} \mathrm{H}-\mathrm{NMR}$ spectra of compounds $18 \mathrm{a}$ and $\mathbf{1 8 b}$ showed signals in the range 1.20-1.27, 1.90-1.97 and 2.21-2.75 ppm attributed to $\mathrm{CH}, \mathrm{CH}_{2}$ and $\mathrm{CH}(\mathrm{CN})_{2}$, respectively, in addition to signals attributed to aromatic, coumarin and $\mathrm{NH}$ protons. The ${ }^{1} \mathrm{H}-\mathrm{NMR}$ spectrum of compound 19 showed signals at $1.22-1.25,2.26-2.30,2.72,7.05-8.34$ and $8.77 \mathrm{ppm}$ attributed to $\mathrm{CH}_{2}, 2 \mathrm{CH}$, aromatic and coumarin protons, respectively.

\subsection{Pharmacological Activity}

\subsubsection{Cytotoxic Activity Using an In Vitro Ehrlich Ascites Assay}

Out of the newly synthesized compounds, twenty three analogs were selected to be evaluated for their in vitro cytotoxic effect against a panel of four human tumor cell lines namely: hepatocellular carcinoma (liver) HepG2, colon cancer HCT-116, human prostate cancer PC3, and mammary gland breast MCF-7 cancer cell lines (Table 1). In general, the activity observed by all of these molecules ranged from very strongly to weakly cytotoxic. The results revealed that 12 of the tested compounds $(5 \mathbf{a}, \mathbf{b}, \mathbf{7 a}, \mathbf{b}, \mathbf{9 a}, \mathbf{b}, \mathbf{1 1} \mathbf{b}, \mathbf{1 3 b}, \mathbf{1 5 a}, \mathbf{b}, \mathbf{1 6} \mathbf{a}$ and $\mathbf{1 8 a})$ exhibited varying degrees of inhibitory activity towards the four tested tumor cell lines, ranging from strong to very strong. As for the activity against 
hepatocellular carcinoma HePG2, the highest cytotoxic activity was displayed by compounds $7 \mathbf{a}, \mathbf{b}$ and $\mathbf{1 5 b}$ which showed $\mathrm{IC}_{50}$ values of $10.8 \pm 0.88,9.3 \pm 0.58$ and $8.2 \pm 0.45 \mu \mathrm{g} / \mathrm{mL}$, respectively. Remarkably strong inhibitory activity ranging from 11.0-19.7 was also seen for compounds 5a, 9a,b, 13b 15a and 18a, while 3, 5b, 10a, 11b, 16a,b and 19 also showed moderate activity and 4, 10b, 11a, $13 a, 17 a, b$ and $18 b$ had weak activity.

Table 1. Cytotoxicity $\left(\mathrm{IC}_{50}\right)$ of the tested compounds on different cell lines.

\begin{tabular}{ccccc}
\hline \multirow{2}{*}{ Comp. No. } & \multicolumn{4}{c}{ IC $_{\mathbf{5 0}}(\mu \mathrm{g} / \mathbf{m L})^{\mathbf{a}}$} \\
\cline { 2 - 5 } & HePG2 & HCT-116 & PC3 & MCF-7 \\
\hline $\mathbf{3}$ & $\mathbf{4 1 . 2} \pm \mathbf{3 . 0 6}$ & $\mathbf{3 6 . 5} \pm \mathbf{0 2 . 5 4}$ & $\mathbf{4 2 . 0} \pm \mathbf{3 . 2 4}$ & $\mathbf{4 5 . 8} \pm \mathbf{3 . 4 0}$ \\
\hline $\mathbf{4}$ & $51.2 \pm 3.62$ & $33.6 \pm 2.64$ & $48.9 \pm 2.91$ & $39.7 \pm 2.35$ \\
$\mathbf{5 a}$ & $12.5 \pm 0.69$ & $12.8 \pm 1.03$ & $16.2 \pm 1.56$ & $15.7 \pm 1.24$ \\
$\mathbf{5 b}$ & $27.6 \pm 1.87$ & $21.8 \pm 2.10$ & $34.0 \pm 2.65$ & $15.8 \pm 1.08$ \\
$\mathbf{7 a}$ & $10.8 \pm 0.88$ & $10.4 \pm 0.94$ & $9.6 \pm 0.382$ & $10.6 \pm 0.92$ \\
$\mathbf{7 b}$ & $9.3 \pm 0.58$ & $4.8 \pm 0.18$ & $11.1 \pm 1.13$ & $7.8 \pm 0.67$ \\
$\mathbf{9 a}$ & $13.1 \pm 0.95$ & $9.4 \pm 0.97$ & $14.5 \pm 1.30$ & $12.0 \pm 1.14$ \\
$\mathbf{9 b}$ & $11.0 \pm 0.98$ & $11.4 \pm 0.87$ & $18.0 \pm 1.96$ & $20.4 \pm 1.56$ \\
$\mathbf{1 0 a}$ & $35.7 \pm 2.54$ & $46.3 \pm 2.35$ & $51.6 \pm 3.61$ & $29.9 \pm 1.97$ \\
$\mathbf{1 0 b}$ & $63.5 \pm 3.94$ & $56.4 \pm 3.35$ & $83.8 \pm 3.58$ & $64.4 \pm 3.84$ \\
$\mathbf{1 1 a}$ & $73.0 \pm 4.35$ & $78.2 \pm 3.98$ & $96.8 \pm 4.87$ & $81.5 \pm 4.21$ \\
$\mathbf{1 1 b}$ & $22.6 \pm 1.36$ & $19.8 \pm 1.63$ & $25.5 \pm 1.74$ & $5.6 \pm 0.43$ \\
$\mathbf{1 3 a}$ & $52.9 \pm 3.62$ & $65.1 \pm 4.11$ & $76.9 \pm 4.65$ & $58.3 \pm 3.63$ \\
$\mathbf{1 3 b}$ & $17.4 \pm 1.25$ & $14.4 \pm 1.01$ & $10.8 \pm 0.79$ & $29.6 \pm 1.87$ \\
$\mathbf{1 5 a}$ & $17.6 \pm 1.05$ & $20.0 \pm 1.44$ & $13.7 \pm 0.94$ & $17.6 \pm 1.37$ \\
$\mathbf{1 5 b}$ & $8.2 \pm 0.45$ & $9.7 \pm 0.84$ & $8.7 \pm 0.45$ & $14.1 \pm 1.21$ \\
$\mathbf{1 6 a}$ & $25.6 \pm 1.67$ & $15.3 \pm 1.13$ & $13.4 \pm 0.96$ & $19.9 \pm 2.14$ \\
$\mathbf{1 6 b}$ & $26.2 \pm 1.13$ & $29.6 \pm 2.25$ & $35.4 \pm 2.13$ & $40.2 \pm 2.64$ \\
$\mathbf{1 7 a}$ & $90.6 \pm 6.57$ & $71.1 \pm 4.82$ & $87.4 \pm 5.14$ & $86.7 \pm 6.15$ \\
$\mathbf{1 7 b}$ & $52.7 \pm 3.41$ & $44.7 \pm 3.12$ & $59.8 \pm 2.35$ & $45.9 \pm 2.89$ \\
$\mathbf{1 8 a}$ & $19.7 \pm 1.20$ & $13.8 \pm 0.89$ & $16.1 \pm 1.08$ & $13.2 \pm 0.76$ \\
$\mathbf{1 8 b}$ & $60.1 \pm 3.24$ & $72.6 \pm 3.86$ & $82.2 \pm 4.32$ & $62.5 \pm 4.35$ \\
$\mathbf{1 9}$ & $25.2 \pm 2.10$ & $22.4 \pm 1.37$ & $28.8 \pm 2.67$ & $25.8 \pm 1.72$ \\
$\mathbf{5 - F U}$ & $7.9 \pm 0.12$ & $5.3 \pm 0.14$ & $8.3 \pm 0.25$ & $5.4 \pm 0.21$ \\
\hline
\end{tabular}

${ }^{\mathrm{a}} \mathrm{IC}_{50}(\mu \mathrm{g} / \mathrm{mL})$ : 1-10 (very strong), 11-20 (strong), 21-50 (moderate), 51-100 (weak), above 100 (non-cytotoxic).

As for the activity against colon cancer HCT-116 cell line, the highest cytotoxic activities were displayed by compounds $\mathbf{7 a , b}, \mathbf{9 a}$ and $\mathbf{1 5 b}$ which showed $\mathrm{IC}_{50}$ at $10.4 \pm 0.94,4.8 \pm 0.18,9.4 \pm 0.97$ and $9.7 \pm 0.84 \mu \mathrm{g} / \mathrm{mL}$, respectively. Compound $7 \mathbf{b}$ showed higher activity than the reference (5-Fu $5.3 \pm 0.14)$. Remarkable strong inhibitory activities were also demonstrated by compounds $5 \mathbf{a}, \mathbf{9 b}, \mathbf{1 1 b}$, 13b, 15a, 16a and 18a ranging 10.4-20.0 $\mu \mathrm{g} / \mathrm{mL}$. Also compounds 3, 4, 5b, 10a, 16b, 17b and 19 showed moderate activity, while compounds $10 \mathrm{~b}, 11 \mathrm{a}, \mathbf{1 3 a}, \mathbf{1 7} \mathrm{a}$ and $\mathbf{1 8 b}$ showed weak activity.

Compounds $\mathbf{7 a}, \mathbf{1 3 b}$ and $\mathbf{1 5 b}$ were found to be the most potent derivatives overall the tested compounds against human prostate cancer cell line PC3 with $\mathrm{IC}_{50} 9.6 \pm 0.82$, $10.8 \pm 0.79$ and $8.7 \pm 0.45 \mu \mathrm{g} / \mathrm{mL}$, respectively. Compound $\mathbf{1 5 b}$ is almost equipotent as 5-fluorouracil $\left(\mathrm{IC}_{50}=8.3 \pm 0.25 \mu \mathrm{g} / \mathrm{mL}\right)$. Also compounds $\mathbf{5 a}, \mathbf{7 b}, \mathbf{9 a}, \mathbf{b}, \mathbf{1 5 a}, \mathbf{1 6} \mathbf{a}$ and 18a were strongly active with $\mathrm{IC}_{50}=16.2 \pm 1.56,11.1 \pm 1.13,14.5 \pm 1.30,18.0 \pm 1.9613 .7 \pm 0.94,13.4 \pm 0.96$ and $16.1 \pm 1.08 \mu \mathrm{g} / \mathrm{mL}$, respectively. On the other hand compounds $3,4,5 b, \mathbf{1 1 b}, \mathbf{1 6 b}$ and 19 showed moderate activity, while compounds $\mathbf{1 0 a}, \mathbf{b}, \mathbf{1 1} \mathbf{a}, \mathbf{1 3} \mathbf{a}, \mathbf{1 7} \mathbf{a}, \mathbf{b}$ and $\mathbf{1 8 b}$ showed weak activity.

Whilst compounds $\mathbf{7} \mathbf{a}, \mathbf{b}$ and $\mathbf{1 1} \mathbf{b}$ showed very strong activity towards mammary gland (breast) MCF-7 with $\mathrm{IC}_{50} 10.6 \pm 0.92,7.8 \pm 0.67$ and $5.6 \pm 0.43 \mu \mathrm{g} / \mathrm{mL}$, respectively, compounds $5 \mathbf{a}, \mathbf{b}$, 9a,b 15a,b, 16a and 18a displayed strong activity, with $\mathrm{IC}_{50}=15.7 \pm 1.24,15.8 \pm 1.08,12.0 \pm 1.14$, $20.4 \pm 1.56,17.6 \pm 1.37,14.1 \pm 1.21,19.9 \pm 2.14$ and $13.2 \pm 0.76 \mu \mathrm{g} / \mathrm{mL}$, respectively. On the other hand compounds $3,4,10 a, 13 b, 16 b, 17 b$ and 19 showed moderate activity, while compounds 10b, 
11a, 13a, 17a and 18b showed weak activity. Compound $\mathbf{1 1 b}$ is almost equipotent to 5-fluorouracil $\left(\mathrm{IC}_{50}=5.4 \pm 0.21 \mu \mathrm{g} / \mathrm{mL}\right)$. Compounds containing the coumarin ring showed higher cytotoxic activity than their analogs containing the benzocoumarin ring (the relative viabilities of cells (\%) for the reference and the tested compounds are listed in Tables S1 and S2 and Figures S1-S24 as Supplementary Materials).

\subsubsection{Antioxidant Activity Using ABTS Inhibition}

Twenty three compounds were tested for antioxidant activity reflected as the ability to inhibit oxidation in rat brain and kidney homogenates (Table 2).

Table 2. Antioxidant activity and bleomycin-dependent DNA damage for the tested compounds ${ }^{\mathrm{a}}$.

\begin{tabular}{|c|c|c|c|}
\hline \multirow{2}{*}{ Comp. No. } & \multicolumn{2}{|c|}{ Antioxidant Activity (ABTS Method) } & \multirow{2}{*}{$\begin{array}{l}\text { Bleomycin Dependent } \\
\text { DNA Damage }\end{array}$} \\
\hline & Absorbance & Inhibition (\%) & \\
\hline 3 & 0.233 & 51.6 & 0.095 \\
\hline 4 & 0.134 & 72.9 & 0.114 \\
\hline $5 a$ & 0.145 & 69.9 & 0.107 \\
\hline $5 \mathbf{b}$ & 0.078 & 84.4 & 0.089 \\
\hline $7 a$ & 0.119 & 75.3 & 0.089 \\
\hline $7 \mathrm{~b}$ & 0.076 & 84.6 & 0.083 \\
\hline $9 a$ & 0.150 & 68.9 & 0.099 \\
\hline $9 b$ & 0.076 & 84.6 & 0.096 \\
\hline $10 a$ & 0.236 & 51.0 & 0.126 \\
\hline $10 \mathrm{~b}$ & 0.217 & 56.2 & 0.131 \\
\hline $11 a$ & 0.248 & 49.9 & 0.142 \\
\hline $11 b$ & 0.077 & 84.4 & 0.072 \\
\hline $13 a$ & 0.244 & 49.4 & 0.145 \\
\hline $13 b$ & 0.076 & 84.6 & 0.105 \\
\hline $15 a$ & 0.201 & 58.3 & 0.094 \\
\hline $15 b$ & 0.118 & 75.5 & 0.076 \\
\hline $16 a$ & 0.195 & 59.5 & 0.089 \\
\hline $16 b$ & 0.232 & 51.9 & 0.106 \\
\hline $17 a$ & 0.290 & 39.8 & 0.18 \\
\hline $17 b$ & 0.152 & 69.3 & 0.127 \\
\hline $18 a$ & 0.164 & 66.0 & 0.081 \\
\hline $18 b$ & 0.274 & 43.1 & 0.125 \\
\hline 19 & 0.213 & 55.8 & 0.124 \\
\hline Ascorbic acid & 0.053 & 89.0 & 0.073 \\
\hline
\end{tabular}

a All experiments were performed three times. The data are expressed as the mean-standard error of the mean (S.E.M.).

Compounds $\mathbf{5 b}, \mathbf{7 b}, \mathbf{9} \mathbf{b}, \mathbf{1 1} \mathbf{b}$ and $\mathbf{1 3 b}$ showed very high inhibitions of $84.4,84.6,84.6,84.4$ and $84.6 \%$, respectively. Compounds $4,5 \mathbf{a}, 7 \mathbf{a}, \mathbf{9 a}, \mathbf{1 5} \mathbf{b}, \mathbf{1 7 b}$ and $\mathbf{1 8 a}$ showed high inhibitions of $72.9,69.9,75.3,68.9,75.5,69.3$ and $66.0 \%$, respectively. In addition the rest of the compounds $3, \mathbf{1 0 a}, \mathbf{b}$, 11a, 13a, 15a, 16a, b, 17a, 18b and 19 exhibited moderate to weak antioxidant activity ranging from $59.5-39.8 \%$. Compounds containing the benzocoumarin ring showed higher antioxidant activity than their analogs containing the coumarin ring.

\subsubsection{Bleomycin-Dependent DNA Damage}

Bleomycins are a family of glycopeptide antibiotics routinely used as antitumor agents. The bleomycin assay has been adopted for assessing the pro-oxidant effect of food antioxidants. The antitumor antibiotic bleomycin binds iron ions and DNA. The bleomycin-iron complex degrades DNA when heated with thiobarbituric acid (TBA) to yield a pink chromogen. Upon the addition of suitable reducing agents the antioxidant competes with DNA and diminishes chromogen formation [47]. 
To show the mechanism of action of the twenty three tested compounds, their protective activity against DNA damage induced by the bleomycin-iron complex was examined. The results (Table 2) showed that compounds $\mathbf{1 1 b}(0.072)$ and $\mathbf{1 5 b}(0.076)$ were equipotent to ascorbic acid (0.073). Consequently, they have the ability to protect DNA from the damage induced by bleomycin. Compounds $3,5 b, 7 a, b, 9 a, b, 15 a, 16 a$ and 18a meanwhile showed high protection against DNA damage induced by the bleomycin-iron complex ranged from $0.081-0.099$. On the other hand, the rest of the compounds exhibited weak activities. Thus, all the tested compounds diminish the chromogen formation between the damage DNA and TBA with different activity. Compounds containing the benzocoumarin ring showed higher activity against DNA damage than their analogs containing the coumarin rings.

\subsubsection{Structure Activity Relationships}

The antitumor activity of natural and synthetic coumarin derivatives has been extensively explored by many researchers $[30,48-50]$ and it has been proven that coumarins, depending on their structure, can act on various tumor cells by different mechanisms, inhibiting the enzyme telomerase, protein kinase activity and downregulating oncogene expression or inducing caspase-9-mediated apoptosis, suppressing cancer cell proliferation by arresting the cell cycle in G0/G1 phase, G2/M phase and affecting the p-groups of cancer cells [51,52].

By comparing the experimental cytotoxicity of the compounds reported in this study to their structures, the following structure activity relationships (SAR) are postulated:

- The cytotoxic activity of compounds 3, 4 is due to the presence of the coumarin moiety and also the formation of intermolecular hydrogen bonds between the $\mathrm{OH}$ [53] and DNA bases.

- The cytotoxic activity of compounds $\mathbf{7 a}, \mathbf{b}$ is due to the presence of the coumarin moiety and also the formation of intermolecular hydrogen bonds of $\mathrm{OH}$ and $\mathrm{NH}_{2}$ groups with DNA bases [52]. Introducing the pyrazole carbothioamide moiety [25] also enhances the cytotoxic activity of compounds $7 \mathbf{a}, \mathbf{b}$.

- The cytotoxic activity of compounds $\mathbf{5 a}, \mathbf{b}$ is due to the presence of the coumarin and the pyrazole carboxylic acid moieties [42] and also the formation of intermolecular hydrogen bonds between the $\mathrm{OH}$ and DNA bases. Compounds $\mathbf{7 a}, \mathbf{b}$ demonstrated better activity compared to compounds $\mathbf{5 a}, \mathbf{b}$, probably due to the presence of the carbothioamide $\left(\mathrm{S}=\mathrm{CNH}_{2}\right)$ moiety.

- Compounds $\mathbf{9 a}, \mathbf{b}$ showed strong activity due to the presence of the coumarin and the pyridazinone rings.

- Compounds $15 a, b$ and $16 a$ showed strong and very strong activity due to the presence of the coumarin and the pyran rings.

- Compounds 18a showed strong activity due to the presence of the coumarin and the pyridazine rings, and also the presence of two cyano groups.

\section{Experimental Section}

\subsection{General Information}

All melting points were measured on a Gallenkamp melting point apparatus and are uncorrected. The infrared spectra were recorded using potassium bromide disks on a Mattson FTIR infrared spectrophotometer (Mattson, New York, NY, USA). ${ }^{1} \mathrm{H}-\mathrm{NMR}$ spectra were run at $300 \mathrm{MHz}$, on a Varian Mercury VX-300 NMR spectrometer (Bruker, Rheinstetten, Germany), using TMS as an internal standard in deuterated dimethylsulphoxide. Chemical shifts $\delta$ are quoted in ppm and $J$ in $\mathrm{Hz}$. The mass spectra were recorded on a GCMS-QP-1000EX mass spectrometer (Shimadzu, Kyoto, Japan) at 70 e.V. All the spectral measurements were carried out at the Microanalytical Center of Cairo University, Cairo, Egypt and the Main Defense Chemical Laboratory, Cairo, Egypt. The elemental analyses were carried out at the Microanalytical center of Ain Shams University, Cairo, Egypt. The pharmaceutical activity 
assays were carried out at Pharmacology Department, Faculty of Pharmacy, EL-Mansoura University, EL-Mansoura, Egypt. All the chemical reactions were monitored by TLC.

\subsection{Synthesis}

\subsubsection{General Procedure for the Synthesis of Compounds 3 and 4}

A mixture of compound 1 and/or $2(0.012 \mathrm{~mol})$ and glyoxalic acid $(0.81 \mathrm{~g}, 0.011 \mathrm{~mol})$ in glacial acetic acid $(20 \mathrm{~mL})$ containing $\mathrm{HCl}(1-2 \mathrm{~mL})$ in the presence of $\mathrm{ZnCl}_{2}(0.5 \mathrm{~g})$ was heated under reflux for $8 \mathrm{~h}$. The reaction mixture was cooled and then poured on hot water to dissolve the $\mathrm{ZnCl}_{2}$. The separated solid was filtered off and washed with water, dried and recrystallized from the proper solvent to give compounds 3 and 4 , respectively.

4-Oxo-4-(2-oxo-2H-chromen-3-yl)but-2-enoic Acid (3). Pale brown crystals; yield (1.8 g, 74\%); m.p. 200-203 ${ }^{\circ} \mathrm{C}$; methanol. IR (KBr) cm ${ }^{-1}$ : $3446(\mathrm{OH}), 1730-1656$ (C=O), 1609 (C=C). ${ }^{1} \mathrm{H}-\mathrm{NMR}$ (DMSO- $d_{6}$ ) $\delta: 7.19-8.66\left(\mathrm{~m}, 6 \mathrm{H}, 4 \mathrm{ArH}, 2 \mathrm{H}\right.$ olefinic), $9.58\left(\mathrm{~s}, 1 \mathrm{H}\right.$, coumarin), 12.51 (s, $1 \mathrm{H}, \mathrm{OH} \mathrm{D} \mathrm{O}_{2} \mathrm{O}$ exchangeable). MS m/z: $244\left([\mathrm{M}]^{+}\right)$(42.9), 199 (42.9), 145 (78.6), 132 (21.4), 131 (71.4), 92 (57.1), 78 (14.3). Anal. Calcd. for $\mathrm{C}_{13} \mathrm{H}_{8} \mathrm{O}_{5}: \mathrm{C}, 63.94 ; \mathrm{H}, 3.30$. Found: $\mathrm{C}, 63.81 ; \mathrm{H}, 3.32$.

4-Oxo-4-(3-oxo-3H-benzo[f]chromen-2-yl)but-2-enoic Acid (4). Brown crystals; yield (2.12 g, 72.2\%); m.p. 229-231 ${ }^{\circ} \mathrm{C}$; dioxane $/ \mathrm{H}_{2} \mathrm{O}(3: 1) .{ }^{1} \mathrm{H}-\mathrm{NMR}$ (DMSO- $\left.d_{6}\right) \delta$ : 7.60-8.11 (m, 8H, $6 \mathrm{ArH}, 2 \mathrm{H}$ olefinic), 8.34 (s, $1 \mathrm{H}$, coumarin), $9.40\left(\mathrm{~s}, 1 \mathrm{H}, \mathrm{OH} \mathrm{D} \mathrm{D}_{2} \mathrm{O}\right.$ exchangeable). IR $(\mathrm{KBr}) \mathrm{cm}^{-1}: 3476(\mathrm{OH}), 1742-1642(\mathrm{C}=\mathrm{O})$, $1627(\mathrm{C}=\mathrm{C}) . \mathrm{MS} \mathrm{m} / z: 296\left([\mathrm{M}+2]^{+}\right)(4.78), 249$ (7.19), 224 (10.25), 223 (76.82), 198 (14.10), 196 (100.0), 181 (24.30), 168 (63.44), 165 (23.65), 156 (35.56), 153 (17.16), 144 (66.47), 127 (41.76), 72 (23.55), 62 (23.57), 56 (20.29), 46 (25.09). Anal. Calcd. for $\mathrm{C}_{17} \mathrm{H}_{10} \mathrm{O}_{5}$ : C, 69.39; H, 3.43. Found: $\mathrm{C}, 69.45 ; \mathrm{H}, 3.46$.

\subsubsection{General Procedure for the Synthesis of Compounds $\mathbf{5 a}$ and $\mathbf{5 b}$}

A mixture of compound 3 and/or $4(0.01 \mathrm{~mol})$, hydrazine hydrate, $(0.50 \mathrm{~mL}, 0.01 \mathrm{~mol})$ in DMF $(20 \mathrm{~mL})$ was refluxed for $3 \mathrm{~h}$, cool, poured on water, The solid that separated was filtered off, dried and recrystallized from the proper solvent to give compounds $5 \mathbf{a}$ and $\mathbf{5 b}$ respectively.

3-(2-Oxo-2H-chromen-3-yl)-1H-pyrazole-5-carboxylic Acid (5a). Brown crystals; yield (2.24 g, 87.5\%); m.p. $>300{ }^{\circ} \mathrm{C} ; \mathrm{DMF} / \mathrm{H}_{2} \mathrm{O}(3: 1) .{ }^{1} \mathrm{H}-\mathrm{NMR}$ (DMSO- $\left.d_{6}\right) \delta: 7.01$ (br.s, $1 \mathrm{H}, \mathrm{NH} \mathrm{D}_{2} \mathrm{O}$ exchangeable,), 6.97-7.96 (m, 5H, 4ArH, =CH), $9.01\left(\mathrm{~s}, 1 \mathrm{H}\right.$, coumarin), 11.03 (br.s, $1 \mathrm{H}, \mathrm{OH} \mathrm{D}_{2} \mathrm{O}$ exchangeable). IR (KBr) cm ${ }^{-1}: 3440(\mathrm{OH}), 3217(\mathrm{NH}), 1720(\mathrm{C}=\mathrm{O}$ coumarin $), 1674(\mathrm{C}=\mathrm{O}$ acid $), 1625(\mathrm{C}=\mathrm{N}) . \mathrm{MS} \mathrm{m} / \mathrm{z}: 256$ $\left([\mathrm{M}]^{+}\right)(0.00), 240$ (10.52), 149 (10.71), 147 (6.00), 136 (39.95), 122 (8.53), 120 (28.24), 93 (66.40), 91 (100), 74 (8.10), 72 (22.02), 60 (40.16), 58 (12.49), 56 (44.58), 54 (50.41), 46 (20.89). Anal. Calcd. for $\mathrm{C}_{13} \mathrm{H}_{8} \mathrm{~N}_{2} \mathrm{O}_{4}$ : C, 60.94; H, 3.15; N, 10.93. Found: C, 60.79; H, 18; N, 10.95.

3-(3-Oxo-3H-benzo[f]chromen-2-yl)-1H-pyrazole-5-carboxylic Acid (5b). Brown crystals; yield (2.47 g, 81\%); m.p. $>300{ }^{\circ} \mathrm{C}$; methanol. ${ }^{1} \mathrm{H}-\mathrm{NMR}$ (DMSO- $\left.d_{6}\right) \delta: 6.99$ (br.s, $1 \mathrm{H}, \mathrm{NH}, \mathrm{D}_{2} \mathrm{O}$ exchangeable, ), 7.11-8.10 (m, $7 \mathrm{H}, 6 \mathrm{ArH},=\mathrm{CH}), 8.86\left(\mathrm{~s}, 1 \mathrm{H}\right.$, coumarin), $12.82\left(\mathrm{~s}, 1 \mathrm{H}, \mathrm{OH}, \mathrm{D}_{2} \mathrm{O}\right.$ exchangeable). $\mathrm{IR}(\mathrm{KBr}) \mathrm{cm}^{-1}: 3400$ $(\mathrm{OH}), 3283(\mathrm{NH}), 1722\left(\mathrm{C}=\mathrm{O}\right.$ coumarin), $1671(\mathrm{C}=\mathrm{O}$ acid $), 1625(\mathrm{C}=\mathrm{N}) . \mathrm{MS} \mathrm{m} / \mathrm{z}(\%): 306\left([\mathrm{M}]^{+}\right)(0.00)$, 262 (0.22), 169 (25.84), 170 (11.60), 144 (28.16), 143 (61.74), 128 (18.61), 127 (11.35), 116 (21.79), 115 (100), 114 (20.20), 68 (0.60). Anal. Calcd. for : $\mathrm{C}_{17} \mathrm{H}_{10} \mathrm{~N}_{2} \mathrm{O}_{4}$ : C, 66.67; H, 3.29; N, 9.15. Found: $\mathrm{C}, 66.69 ; \mathrm{H}, 3.30$; N, 9.16 .

\subsubsection{S General Procedure for the Synthesis of Compounds $\mathbf{6 a}$ and $\mathbf{6 b}$}

A mixture of compound 3 and/or $4(0.01 \mathrm{~mol})$, and hydroxylamine hydrochloride $(0.69 \mathrm{~g}, 0.01 \mathrm{~mol})$ in pyridine $(20 \mathrm{~mL})$ was refluxed for $3 \mathrm{~h}$, cool, poured on ice/ $\mathrm{HCl}$, The 
solid that separated was filtered off, dried and recrystallized from the proper solvent to give compounds $6 \mathbf{a}$ and $6 \mathrm{~b}$ respectively.

5-(2-Oxo-2H-chromen-3-yl)-2,3-dihydroisoxazole-3-carboxylic Acid (6a). Reddish brown crystals; yield (1.49 g, 57.9\%); m.p. $230-232{ }^{\circ} \mathrm{C}$; methanol $/ \mathrm{H}_{2} \mathrm{O}(2: 1) .{ }^{1} \mathrm{H}-\mathrm{NMR}$ (DMSO- $\left.d_{6}\right) \delta: 4.05(\mathrm{~d}, 1 \mathrm{H}, \mathrm{CH})$, 6.91-7.80 (m, 5H, 4ArH, =CH), $9.05\left(\mathrm{~s}, 1 \mathrm{H}\right.$, coumarin), $10.10\left(\mathrm{~s}, 1 \mathrm{H}, \mathrm{NH} \mathrm{D} \mathrm{D}_{2} \mathrm{O}\right.$ exchangeable), 11.90 (s, 1H, OH, $\mathrm{D}_{2} \mathrm{O}$ exchangeable). IR $(\mathrm{KBr}) \mathrm{cm}^{-1}: 3393(\mathrm{OH}), 3204(\mathrm{NH}), 1720(\mathrm{C}=\mathrm{O}$ coumarin $), 1710$ (C=O acid), $1610(\mathrm{C}=\mathrm{N})$. MS m/z: $260\left([\mathrm{M}+1]^{+}\right)(4.98), 243$ (15.22), 215 (25.33), 146 (39.80), 118 (32.05), 115 (29.27), 104 (19.70), 91 (52.46), 78 (69.66), 71 (47.66), 57 (68.36), 55 (57.48), 46 (43.66), 45 (100). Anal. Calcd. for $\mathrm{C}_{13} \mathrm{H}_{9} \mathrm{NO}_{5}: \mathrm{C}, 60.24 ; \mathrm{H}, 3.50 ; \mathrm{N}, 5.40$. Found: $\mathrm{C}, 61.12 ; \mathrm{H}, 3.49 ; \mathrm{N}, 5.37$.

5-(3-Oxo-3H-benzo[f]chromen-2-yl)-2,3-dihydroisoxazole-3-carboxylic Acid (6b). Pale brown crystals; yield (1.79 g, 58.25\%); m.p. $174-175^{\circ} \mathrm{C}$; methanol. ${ }^{1} \mathrm{H}-\mathrm{NMR}$ (DMSO- $\left.d_{6}\right) \delta: 4.13(\mathrm{~d}, 1 \mathrm{H}, \mathrm{CH}), 6.93(\mathrm{~s}, 1 \mathrm{H}$, $\mathrm{NH} \mathrm{D}_{2} \mathrm{O}$ exchangeable), 7.18-8.79 $(\mathrm{m}, 7 \mathrm{H}, 6 \mathrm{ArH},=\mathrm{CH}), 9.03\left(\mathrm{~s}, 1 \mathrm{H}\right.$, coumarin), $11.52\left(\mathrm{~s}, 1 \mathrm{H}, \mathrm{OH} \mathrm{D}_{2} \mathrm{O}\right.$ exchangeable). IR ( $\mathrm{KBr}) \mathrm{cm}^{-1}$ : $3380(\mathrm{OH}), 3128(\mathrm{NH}), 1728$ ( $\mathrm{C}=\mathrm{O}$ coumarin), 1718 ( $\mathrm{C}=\mathrm{O}$ acid), 1627 $(\mathrm{C}=\mathrm{N}) . \mathrm{MS} m / z: 309\left([\mathrm{M}]^{+}\right)(0.56), 170$ (13.27), 144 (11.23), 141 (18.27), 140 (17.02), 115 (22.51), 114 (33.80), 79 (100), 78 (17.90), 71 (16.18), 70 (15.40), 57 (30.65). Anal. Calcd. for $\mathrm{C}_{17} \mathrm{H}_{11} \mathrm{NO}_{5}$ : C, 66.02; $\mathrm{H}, 3.58$; N, 4.53. Found: C, 66.11; H, 3.60; N, 4.52.

\subsubsection{General Procedure for the Synthesis of Compounds $7 \mathbf{a}$ and $7 \mathbf{b}$}

A mixture compound 3 and/or $4(0.01 \mathrm{~mol})$, thiosemicarbazide hydrochloride, $(1.27 \mathrm{~g}, \mathrm{~mL}$, $0.01 \mathrm{~mol})$ in DMF $(20 \mathrm{~mL})$ was refluxed for $3 \mathrm{~h}$, cool, poured on water, The solid that separated was filtered off, dried and recrystallized from the proper solvent to give compounds $7 \mathbf{a}$ and $\mathbf{7 b}$ respectively.

1-Carbamothioyl-5-(2-oxo-2H-chromen-3-yl)-1H-pyrazole-3-carboxylic Acid (7a). Brown crystals; yield (2.32 g, 73.8\%); m.p. $253-255{ }^{\circ} \mathrm{C}$; DMF/ $\mathrm{H}_{2} \mathrm{O}$ (3:1). ${ }^{1} \mathrm{H}-\mathrm{NMR}$ (DMSO- $d_{6}$ ) $\delta: 55.71$ (s, $2 \mathrm{H}, \mathrm{NH}_{2}$, $\mathrm{D}_{2} \mathrm{O}$ exchangeable), 6.93-7.52 (m, 5H, ArH, $\left.=\mathrm{CH}\right), 7.94\left(\mathrm{~s}, 1 \mathrm{H}\right.$, coumarin), $12.26\left(\mathrm{~s}, 1 \mathrm{H}, \mathrm{OH}, \mathrm{D}_{2} \mathrm{O}\right.$ exchangeable). IR (KBr) $v_{\max } / \mathrm{cm}^{-1}: 3455(\mathrm{OH}), 3406,3382\left(\mathrm{NH}_{2}\right), 1711(\mathrm{C}=\mathrm{O}$ coumarin $), 1647(\mathrm{C}=\mathrm{O}$ acid), $1607(\mathrm{C}=\mathrm{N})$. MS m/z: $315\left([\mathrm{M}]^{+}\right)(0.00), 314\left([\mathrm{M}-1]^{+}\right)$(3.07) 299 (2.35), 145 (3.65), 117 (3.85), 74 (6.31), 73 (100), 60 (25.43), 58 (15.94), 57 (82.07). Anal. Calcd for $\mathrm{C}_{14} \mathrm{H}_{9} \mathrm{~N}_{3} \mathrm{O}_{4} \mathrm{~S}: \mathrm{C}, 53.33 ; \mathrm{H}, 2.88 ; \mathrm{N}$, 13.33; S, 10.17. Found: C, 53.70; H, 2.78; N, 13.40; S, 10.05 .

1-Carbamothioyl-5-(3-oxo-3H-benzo[f]chromen-2-yl)-1H-pyrazole-3-carboxylic Acid (7b). Brown crystals; yield (2.38 g, 65.4\%); m.p. $220-223{ }^{\circ} \mathrm{C}$; DMF $/ \mathrm{H}_{2} \mathrm{O}(3: 1) .{ }^{1} \mathrm{H}-\mathrm{NMR}$ (DMSO- $\left.d_{6}\right) \delta: 6.48\left(\mathrm{~s}, 2 \mathrm{H}, \mathrm{NH}_{2}, \mathrm{D}_{2} \mathrm{O}\right.$ exchangeable), 7.26-8.62 (m, 7H, 6ArH, $=\mathrm{CH}) 8.65\left(\mathrm{~s}, 1 \mathrm{H}\right.$ coumarin), $12.0\left(\mathrm{~s}, 1 \mathrm{H}, \mathrm{OH}, \mathrm{D}_{2} \mathrm{O}\right.$ exchangeable). IR (KBr) cm ${ }^{-1}$ : $3455(\mathrm{OH}), 3419,3397\left(\mathrm{NH}_{2}\right), 1712(\mathrm{C}=\mathrm{O}$ coumarin), $1653(\mathrm{C}=\mathrm{O}$ acid $), 1625(\mathrm{C}=\mathrm{N})$. MS m/z: $367\left([\mathrm{M}+2]^{+}\right)(0.93), 340$ (12.65), 115 (18.67), 73 (100), 58 (9.22). Anal. Calcd for $\mathrm{C}_{18} \mathrm{H}_{11} \mathrm{~N}_{3} \mathrm{O}_{4} \mathrm{~S}$ : C, 59.17; H, 3.03; N, 11.50; S, 8.78. Found: C, 59.28; H, 3.05; N, 11.53; S, 8.80.

\subsubsection{General Procedure for the Synthesis of Compounds $\mathbf{8 a}$ and $\mathbf{8 b}$}

A mixture of compound 3 and/or $4(0.01 \mathrm{~mol})$ and ammonium acetate $(1.54 \mathrm{~g}, 0.02 \mathrm{~mol})$ was fused at $150-170{ }^{\circ} \mathrm{C}$ for $4 \mathrm{~h}$. The reaction mixture poured onto ice $/ \mathrm{HCl}$. The solid that separated was filtered off, dried and recrystallized from the proper solvent to give compounds $\mathbf{8 a}$ and $\mathbf{8 b}$ respectively.

3-(5-Oxo-5H-pyrrol-2-yl)quinolin-2(1H)-one (8a). Brown crystals; yield (1.69 g, 75.4\%); m.p. > $300{ }^{\circ} \mathrm{C}$; $\mathrm{DMF} / \mathrm{H}_{2} \mathrm{O}(3: 1) .{ }^{1} \mathrm{H}-\mathrm{NMR}\left(\mathrm{DMSO}-d_{6}\right) \delta: 4.91(\mathrm{~d}, 1 \mathrm{H}, \mathrm{CH}=\mathrm{CHCO}), 5.12(\mathrm{~d}, 1 \mathrm{H}, \mathrm{CH}=\mathrm{CHCO}), 7.00-7.95$ (m, 5H, 4ArH,1H, coumarin); $9.57\left(\mathrm{~s}, 1 \mathrm{H}, \mathrm{NH}, \mathrm{D}_{2} \mathrm{O}\right.$ exchangeable). IR $(\mathrm{KBr}) \mathrm{cm}^{-1}: 3181(\mathrm{NH}), 1710$, $1660(\mathrm{C}=\mathrm{O}), 1607(\mathrm{C}=\mathrm{N}) . \mathrm{MS} m / z: 224\left([\mathrm{M}]^{+}\right)(0.00), 225\left([\mathrm{M}+1]^{+}\right)(21.10), 145$ (20.13), 104 (12.53), 81 (24.42), 73 (100), 57 (41.93). Anal. Calcd for $\mathrm{C}_{13} \mathrm{H}_{8} \mathrm{~N}_{2} \mathrm{O}_{2}: \mathrm{C}, 69.64 ; \mathrm{H}, 3.60 ; \mathrm{N}, 12.49$. Found: $\mathrm{C}, 69.80$; $\mathrm{H}, 3.78 ; \mathrm{N}, 12.46$. 
2-(5-Oxo-5H-pyrrol-2-yl)benzo[f $]$ quinolin-3(4H)-one (8b). Brown crystals; yield (1.89 g, 69\%); m.p. 254-256 ${ }^{\circ} \mathrm{C}$; DMF/EtOH (2:1). ${ }^{1} \mathrm{H}-\mathrm{NMR}\left(\mathrm{DMSO}_{-} d_{6}\right) \delta:$ 7.06-8.16 (m, 8H, 6ArH, $1 \mathrm{H}$, coumarin, $2 \mathrm{H}$, $2=\mathrm{CH}), 9.71\left(\mathrm{~s}, 1 \mathrm{H}, \mathrm{NH}, \mathrm{D}_{2} \mathrm{O}\right.$ exchangeable). IR $(\mathrm{KBr}) \mathrm{cm}^{-1}: 1713,1642(\mathrm{C}=\mathrm{O}), 1626(\mathrm{C}=\mathrm{N}) . \mathrm{MS} \mathrm{m} / \mathrm{z}$ : $274\left([\mathrm{M}]^{+}\right)$(0.00), 196 (46.29), 195 (13.87), 170 (16.14), 156 (22.43), 128 (33.78), 80 (100), 74 (6.75). Anal. Calcd. for $\mathrm{C}_{17} \mathrm{H}_{10} \mathrm{~N}_{2} \mathrm{O}_{2}$ : C, 74.44; $\mathrm{H}, 3.67 ; \mathrm{N}, 10.21$. Found: $\mathrm{C}, 74.63 ; \mathrm{H}, 3.64 ; \mathrm{N}, 10.31$.

\subsubsection{General Procedure for the Synthesis of Compounds (9-12)a,b}

A mixture of compound 3 and/or $4(0.01 \mathrm{~mol})$, urea, thiourea, guanidine hydrochloride and cyano thioactamide $(0.01 \mathrm{~mol})$ in DMF $(20 \mathrm{~mL})$ was refluxed for $3 \mathrm{~h}$, cool, poured on water, The solid that separated was filtered off, dried and recrystallized from the proper solvent to give compounds $\mathbf{9 - 1 2}(\mathbf{a}, \mathbf{b})$, respectively.

2-Oxo-6-(2-oxo-2H-chromen-3-yl)-2,5-dihydropyrimidine-4-carboxylic Acid (9a). Brown crystals; yield (2.08 g, 73.4\%); m.p. $237-239{ }^{\circ} \mathrm{C}$; dioxane $/ \mathrm{H}_{2} \mathrm{O}(3: 1) .{ }^{1} \mathrm{H}-\mathrm{NMR}$ (DMSO- $\left.d_{6}\right) \delta: 1.22\left(\mathrm{~s}, 2 \mathrm{H}, \mathrm{CH}_{2}\right.$ methylene), 7.03-8.59 (m, 4H, ArH), $9.01\left(\mathrm{~s}, 1 \mathrm{H}\right.$, coumarin), $11.23\left(\mathrm{~s}, 1 \mathrm{H}, \mathrm{OH}\right.$ exchangeable with $\left.\mathrm{D}_{2} \mathrm{O}\right)$. IR (KBr) cm ${ }^{-1}: 3455(\mathrm{OH}), 1720-1674(\mathrm{C}=\mathrm{O}), 1624(\mathrm{C}=\mathrm{N}), 1610(\mathrm{C}=\mathrm{C}) . \mathrm{MS} \mathrm{m} / \mathrm{z}: 284\left([\mathrm{M}]^{+}, 14.42\right)$, 240 (15.34), 212 (23.51), 190 (14.49), 184 (16.77), 170 (14.97), 98 (37.20), 60 (100). Anal. Calcd. for $\mathrm{C}_{14} \mathrm{H}_{8} \mathrm{~N}_{2} \mathrm{O}_{5}$ : C, 59.16; $\mathrm{H}, 2.84 ; \mathrm{N}, 9.86$. Found: $\mathrm{C}, 59.20 ; \mathrm{H}, 2.90 ; \mathrm{N}, 9.75$.

2-Oxo-6-(3-oxo-3H-benzo[f]chromen-2-yl)-2,5-dihydropyrimidine-4-carboxylic Acid (9b). Brown crystals; yield (2.18 g, 65.47\%); m.p. $274-276{ }^{\circ} \mathrm{C}$; DMF $/ \mathrm{H}_{2} \mathrm{O}(3: 1) .{ }^{1} \mathrm{H}-\mathrm{NMR}$ (DMSO- $d_{6}$ ) $\delta: 1.20\left(\mathrm{~s}, 2 \mathrm{H}, \mathrm{CH}_{2}\right.$ methylene), 6.61-8.93 (m, 6H, ArH), $9.05\left(\mathrm{~s}, 1 \mathrm{H}\right.$, coumarin), $10.25\left(\mathrm{~s}, 1 \mathrm{H}, \mathrm{OH}, \mathrm{D}_{2} \mathrm{O}\right.$ exchangeable). IR $(\mathrm{KBr}) \mathrm{cm}^{-1}: 3437(\mathrm{OH}), 1720-1642(\mathrm{C}=\mathrm{O}), 1626(\mathrm{C}=\mathrm{N}) . \mathrm{MS} \mathrm{m} / \mathrm{z}: 334\left([\mathrm{M}]^{+}, 0.00\right), 289$ (47.5), 196 (27.51), 170 (10.0), 158 (42.5), 96 (44.3), 80 (100). Anal. Calcd. for $\mathrm{C}_{18} \mathrm{H}_{10} \mathrm{~N}_{2} \mathrm{O}_{5}: \mathrm{C}, 64.67 ; \mathrm{H}, 3.02 ; \mathrm{N}$, 8.38. Found: C, $64.82 ; \mathrm{H}, 3.04 ; \mathrm{N}, 8.35$.

6-(2-Oxo-2H-chromen-3-yl)-2-thioxo-2,5-dihydropyrimidine-4-carboxylic Acid (10a). Brown crystals; m.p. 150-153 ${ }^{\circ} \mathrm{C}$; yield (2.38 g, 79.4\%); dioxane/ $\mathrm{H}_{2} \mathrm{O}(3: 1) .{ }^{1} \mathrm{H}-\mathrm{NMR}$ (DMSO- $\left.d_{6}\right) \delta: 1.22\left(\mathrm{~s}, 2 \mathrm{H}, \mathrm{CH}_{2}\right.$ methylene), $6.89-8.59(\mathrm{~m}, 4 \mathrm{H}, \mathrm{ArH}), 9.00\left(\mathrm{~s}, 1 \mathrm{H}\right.$, coumarin), $11.23\left(\mathrm{~s}, 1 \mathrm{H}, \mathrm{OH}\right.$ exchangeable with $\left.\mathrm{D}_{2} \mathrm{O}\right)$. IR $(\mathrm{KBr}) \mathrm{cm}^{-1}: 3384(\mathrm{OH}), 1720(\mathrm{C}=\mathrm{O}$ coumarin), $1708(\mathrm{C}=\mathrm{O}$ acid $), 1627(\mathrm{C}=\mathrm{N}), 1610(\mathrm{C}=\mathrm{C}), 1223$ $(\mathrm{C}=\mathrm{S})$. MS m/z: 300 ([M]+ ) (0.96), 257 (13.01), 256 (16.03), 225 (11.13), 213 (12.16), 185 (10.60), 150 (21.69), 149 (17.38), 136 (18.33), 119 (15.30), 111 (14.99), 79 (12.65), 72 (13.48), 70 (37.28), 68 (14.13), 67 (21.49), 69 (100). Anal. Calcd. for $\mathrm{C}_{14} \mathrm{H}_{8} \mathrm{~N}_{2} \mathrm{O}_{4} \mathrm{~S}: \mathrm{C}, 56.00 ; \mathrm{H}, 2.69 ; \mathrm{N}, 9.33 ; \mathrm{S}, 10.68$. Found: $\mathrm{C}, 55.98 ; \mathrm{H}, 2.70$; $\mathrm{N}, 9.32 ; \mathrm{S}, 10.67$.

6-(3-Oxo-3H-Benzo[f]chromen-2-yl)-2-thioxo-2,5-dihydropyrimidine-4-carboxy-lic Acid (10b). Brown crystals; yield (3.08 g, 88\%); m.p. $249-251{ }^{\circ} \mathrm{C}$; DMF $/ \mathrm{H}_{2} \mathrm{O}(3: 1) .{ }^{1} \mathrm{H}-\mathrm{NMR}$ (DMSO- $d_{6}$ ) $\delta: 1.23(\mathrm{~s}, 2 \mathrm{H}), 6.90-8.05$ (m, 6H), $8.75(\mathrm{~s}, 1 \mathrm{H}), 9.78(\mathrm{~s}, 1 \mathrm{H})$. IR (KBr) $\mathrm{cm}^{-1}: 3368,1714,1708,1627,1213 . \mathrm{MS} m / z: 352\left([\mathrm{M}+2]^{+}\right)$, 322 (10.21), 310 (8.57), 287 (15.06), 212 (22.06), 197 (21.27), 186 (17.49), 170 (15.20), 155 (13.28), 98 (99.00), 72 (25.98), 65 (100), 56 (46.47). Anal. Calcd. for $\mathrm{C}_{18} \mathrm{H}_{10} \mathrm{~N}_{2} \mathrm{O}_{4} \mathrm{~S}: \mathrm{C}, 61.71 ; \mathrm{H}, 2.88 ; \mathrm{N}, 8.00 ; \mathrm{S}, 9.15$. Found: C, 61.80; H, 2.87; N, 7.89; S, 9.14.

2-Imino-6-(2-oxo-2H-chromen-3-yl)-2,5-dihydropyrimidine-4-carboxylic Acid (11a). Deep brown crystals; yield (1.88 g, 66.4\%); m.p. $228-231{ }^{\circ} \mathrm{C}$; dioxane $/ \mathrm{H}_{2} \mathrm{O}(3: 1) ;{ }^{1} \mathrm{H}-\mathrm{NMR}$ (DMSO- $\left.d_{6}\right) \delta: 1.23\left(\mathrm{~s}, 2 \mathrm{H}, \mathrm{CH}_{2}\right.$ methylene), 6.90-8.05 (m, 6H, ArH), $8.75\left(\mathrm{~s}, 1 \mathrm{H}\right.$, coumarin), $9.78\left(\mathrm{~s}, 1 \mathrm{H}, \mathrm{OH}\right.$, exchangeable with $\left.\mathrm{D}_{2} \mathrm{O}\right)$. IR (KBr) cm ${ }^{-1}$ : $3368(\mathrm{OH}), 1714(\mathrm{C}=\mathrm{O}$ coumarin), $1708(\mathrm{C}=\mathrm{O}$ acid $), 1627(\mathrm{C}=\mathrm{N}), 1213(\mathrm{C}=\mathrm{S}) . \mathrm{MS} \mathrm{m} / \mathrm{z}$ : $352\left([\mathrm{M}+2]^{+}\right),(7.49), 322$ (10.21), 310 (8.57), 287 (15.06), 212 (22.06), 197 (21.27), 186 (17.49), 170 (15.20), 155 (13.28), 98 (99.00), 72 (25.98), 65 (100), 56 (46.47). Anal. Calcd. for $\mathrm{C}_{14} \mathrm{H}_{9} \mathrm{~N}_{3} \mathrm{O}_{4}: \mathrm{C}, 59.37 ; \mathrm{H}, 3.20 ; \mathrm{N}$, 14.84. Found: C, 59.35; H, 3.21; N, 14.85 . 
2-Imino-6-(3-oxo-3H-benzo[f]chromen-2-yl)-2,5-dihydropyrimidine-4-carboxylic Acid (11b). Deep brown crystals; yield (2.48 g, 74.6\%); m.p. 155-157 ${ }^{\circ} \mathrm{C}$; DMF. ${ }^{1} \mathrm{H}-\mathrm{NMR}$ (DMSO- $d_{6}$ ) $\delta: 1.21$ (s, $\left.2 \mathrm{H}, \mathrm{CH}_{2}\right), 2.46$ (s, $1 \mathrm{H}, \mathrm{NH}, \mathrm{D}_{2} \mathrm{O}$ exchangeable), 7.17-8.21 (m, 8H, 7Ar-H, 1H coumarin). IR (KBr) cm ${ }^{-1}: 3418(\mathrm{OH}), 3063$ (NH), 1728 (C=O coumarin), 1709 ( $\mathrm{C}=\mathrm{O}$ acid). MS m/z: 335 ([M + 2] $\left.]^{+}\right),(0.95), 196$ (46.29), 198 (38.27), 139 (46.56), 128 (38.16), 116 (19.92), 74 (31.27), 63 (100), 58 (70.77). Anal. Calcd. for $\mathrm{C}_{18} \mathrm{H}_{11} \mathrm{~N}_{3} \mathrm{O}_{4}$ : C, 64.86; H, 3.33; N, 12.61. Found: C, 64.80; H, 3.29; N, 12.54 .

6-(2-Oxo-2H-chromen-3-yl)-2-thioxo-2,5-dihydropyridine-3-carbonitrile (12a). Brown crystals; yield (1.67 g, 59.8\%); m.p. $>300{ }^{\circ} \mathrm{C} .{ }^{1} \mathrm{H}-\mathrm{NMR}\left(\mathrm{DMSO}_{6}\right) \delta: 1.27\left(\mathrm{~d}, 2 \mathrm{H}, \mathrm{CH}_{2}\right), 6.22-7.94(\mathrm{~m}, 6 \mathrm{H}, 4 \mathrm{ArH},=\mathrm{CH}, 1 \mathrm{H}$, coumarin). IR (KBr) cm ${ }^{-1}: 2209(\mathrm{C} \equiv \mathrm{N}), 1713(\mathrm{C}=\mathrm{O}) . \mathrm{MS} m / z: 280\left([\mathrm{M}]^{+}\right)(2.14), 167$ (33.41), 149 (100), 71 (30.33). Anal. Calcd. for $\mathrm{C}_{15} \mathrm{H}_{8} \mathrm{~N}_{2} \mathrm{O}_{2} \mathrm{~S}: \mathrm{C}, 64.27 ; \mathrm{H}, 2.88 ; \mathrm{N}, 9.99 ; \mathrm{S}, 11.44$. Found: $\mathrm{C}, 64.30 ; \mathrm{H}, 2.87 ; \mathrm{N}$, 10.02; S, 11.43 .

6-(3-Oxo-3H-benzo[f]chromen-2-yl)-2-thioxo-2,5-dihydropyridine-3-carbonitrile (12b). Brown crystals; yield $(1.49$ g, $45.2 \%)$; m.p. $>300{ }^{\circ} \mathrm{C} ; \mathrm{DMF} / \mathrm{H}_{2} \mathrm{O}(3: 1) .{ }^{1} \mathrm{H}-\mathrm{NMR}$ (DMSO- $\left.d_{6}\right) \delta: 1.20\left(\mathrm{~d}, 2 \mathrm{H}, \mathrm{CH}_{2}\right), 6.81-7.95(\mathrm{~m}$, $8 \mathrm{H}, 6 \mathrm{ArH},=\mathrm{CH}, 1 \mathrm{H}$, coumarin). IR $(\mathrm{KBr}) \mathrm{cm}^{-1}: 2207(\mathrm{C} \equiv \mathrm{N}), 1705(\mathrm{C}=\mathrm{O}) . \mathrm{MS} m / z: 332\left([\mathrm{M}+2]^{+}\right)(2.97)$, 211 (13.22), 139 (20.64), 57 (92.51), 55 (100). Anal. Calcd. for $\mathrm{C}_{19} \mathrm{H}_{10} \mathrm{~N}_{2} \mathrm{O}_{2} \mathrm{~S}: \mathrm{C}, 69.08 ; \mathrm{H}, 3.05 ; \mathrm{N}, 8.48$; S, 9.71. Found: $\mathrm{C}, 69.15 ; \mathrm{H}, 3.03 ; \mathrm{N}, 8.46 ; \mathrm{S}, 9.70$.

\subsubsection{General Procedure for the Synthesis of Compounds 13a,b}

A mixture of compound 3 and/or $4(0.01 \mathrm{~mol})$, and sodium azide $(0.65 \mathrm{~g}, 0.01 \mathrm{~mol})$ in DMF $(30 \mathrm{~mL})$ was refluxed for $3 \mathrm{~h}$, The mixture was poured onto iced water and the solid obtained was filtered off, dried and recrystallized from the proper solvent to give compounds $13 \mathbf{a}$ and $13 \mathbf{b}$, respectively.

3-(1,2,3-Triazin-4-yl)-2H-chromen-2-one (13a). Pale brown crystals; yield (2.00 g, 89.2\%); m.p. 270-272 ${ }^{\circ} \mathrm{C}$; dioxane $/ \mathrm{H}_{2} \mathrm{O}(3: 1) .{ }^{1} \mathrm{H}-\mathrm{NMR}$ (DMSO- $\left.d_{6}\right) \delta: 6.60-8.20(\mathrm{~m}, 6 \mathrm{H}, 4 \mathrm{ArH}, 2=\mathrm{CH}), 8.89$ (s, $1 \mathrm{H}$, coumarin). IR (KBr) cm ${ }^{-1}: 1718(\mathrm{C}=\mathrm{O}), 1631(\mathrm{C}=\mathrm{N})$. MS m/z: $227\left([\mathrm{M}+2]^{+}\right)$(16.37), 200 (24.66), 199 (25.61), 189 (22.85), 175 (21.17), 157 (20.19), 147 (23.03), 145 (28.23), 133 (25.42), 124 (19.35), 110 (24.98), 103 (27.33), 92 (23.60), 85 (19.39), 74 (13.75), 73 (100). Anal. Calcd. for $\mathrm{C}_{12} \mathrm{H}_{7} \mathrm{~N}_{3} \mathrm{O}_{2}: \mathrm{C}, 64.00 ; \mathrm{H}, 3.13 ; \mathrm{N}, 18.66$. Found: C, 64.16; H, 3.14; N, 18.69 .

2-(1,2,3-Triazin-4-yl)-3H-benzo[f]chromen-3-one (13b). Brown crystals; yield (1.72 g, 62.7\%); m.p. > $300{ }^{\circ} \mathrm{C}$; $\mathrm{DMF} / \mathrm{H}_{2} \mathrm{O}(3: 1) .{ }^{1} \mathrm{H}-\mathrm{NMR}$ (DMSO- $\left.d_{6}\right) \delta: 6.42-8.16(\mathrm{~m}, 8 \mathrm{H}, 6 \mathrm{ArH}, 2=\mathrm{CH}), 8.22$ (s, $1 \mathrm{H}$, coumarin). IR $(\mathrm{KBr}) \mathrm{cm}^{-1}: 1707(\mathrm{C}=\mathrm{O}), 1624(\mathrm{C}=\mathrm{N}) . \mathrm{MS} m / z: 275\left([\mathrm{M}]^{+}\right)(0.09), 196$ (0.98), 98 (98.39), 80 (100), 66 (12.96), 64 (97.95). Anal. Calcd. for $\mathrm{C}_{16} \mathrm{H}_{9} \mathrm{~N}_{3} \mathrm{O}_{2}: \mathrm{C}, 69.81 ; \mathrm{H}, 3.30 ; \mathrm{N}, 15.27$. Found: $\mathrm{C}, 69.87 ; \mathrm{H}, 3.29 ; \mathrm{N}, 15.24$.

\subsubsection{General Procedure for the Synthesis of Compounds 14a,b}

A mixture of compound 3 and/or $4(0.01 \mathrm{~mol})$ and Lawesson's reagent $(4.0 \mathrm{~g}, 0.01 \mathrm{~mol})$ was refluxed in acetonitrile $(30 \mathrm{~mL})$ for $28 \mathrm{~h}$. The reaction mixture was filtered while hot and the filtrate was left to cool at room temperature. The obtained solid was filtered off, dried and recrystallized from the proper solvent to give compounds $14 \mathrm{a}$ and $\mathbf{1 4 b}$ respectively.

3-(5-Hydroxythiophen-2-yl)-2H-thiochromen-2-one (14a) Pale brown crystals; yield (1.99 g, 76.9\%); m.p. 250-253 ${ }^{\circ} \mathrm{C}$; ethanol/DMF (2:1). ${ }^{1} \mathrm{H}-\mathrm{NMR}\left(\mathrm{DMSO}-d_{6}\right) \delta: 6.91(\mathrm{~d}, 1 \mathrm{H},=\mathrm{CH}), 7.14\left(\mathrm{~s}, 1 \mathrm{H}, \mathrm{OH} \mathrm{D} \mathrm{O}_{2}\right.$ exchangeable), 7.54-7.61 (m, 6H, 4ArH, $=\mathrm{CH}, 1 \mathrm{H}$ coumarin). $\mathrm{IR}(\mathrm{KBr}) \mathrm{cm}^{-1} 3557(\mathrm{OH}), 1724(\mathrm{C}=\mathrm{O})$, $1602(\mathrm{C}=\mathrm{C}) . \mathrm{MS} m / z: 261\left([\mathrm{M}+1]^{+}\right)(0.13), 188$ (100), 108 (62.03), 94 (19.60), 92 (16.20), 77 (39.43), 62 (33.50), 46 (28.69). Anal. Calcd. for $\mathrm{C}_{13} \mathrm{H}_{8} \mathrm{O}_{2} \mathrm{~S}_{2}$ : C, 59.98; H, 3.10; S, 24.63. Found: C, 59.91; H, 3.13; S, 24.66 . 
2-(5-Hydroxythiophen-2-yl)-3H-benzo[f]thiochromen-3-one (14b). Brown crystals; yield (1.76 g, 56.9\%); m.p. $>300{ }^{\circ} \mathrm{C} ; \mathrm{DMF} / \mathrm{H}_{2} \mathrm{O}$ (3:1). ${ }^{1} \mathrm{H}-\mathrm{NMR}\left(\mathrm{DMSO}-d_{6}\right)$ 8: 6.20 (s, $1 \mathrm{H}, \mathrm{OH}, \mathrm{D}_{2} \mathrm{O}$ exchangeable), $6.93(\mathrm{~d}, 1 \mathrm{H}, J=3.00,=\mathrm{CH}), 6.96(\mathrm{~d}, 1 \mathrm{H}, J=3.00,=\mathrm{CH}), 7.37-8.64(\mathrm{~m}, 6 \mathrm{H}, \mathrm{ArH}), 9.28(\mathrm{~s}, 1 \mathrm{H}$, coumarin). IR (KBr) cm ${ }^{-1} 3428(\mathrm{OH}), 1724(\mathrm{C}=\mathrm{O}), 1630(\mathrm{C}=\mathrm{C})$. MS m/z (\%): $310\left([\mathrm{M}]^{+}\right)(8.69), 282$ (13.31), 172 (12.06), 128 (11.51), 86 (22.08), 84 (48.17), 70 (25.06), 57 (100). Anal. Calcd. for $\mathrm{C}_{17} \mathrm{H}_{10} \mathrm{O}_{2} \mathrm{~S}_{2}$ : C, 65.78; H, 3.25; S, 20.66. Found: C, 59.95; H, 3.23; S, 20.65.

\subsubsection{General Procedure for the Synthesis of Compounds (15-17)a,b}

A mixture of compound 3 and/or $4(0.01 \mathrm{~mol})$, diethyl malonate, ethyl cyanoacetate and malononitrile $(0.01 \mathrm{~mol})$ in dry acetone $(30 \mathrm{~mL})$ was refluxed on a water bath for $24 \mathrm{~h}$ in the presence of $\mathrm{K}_{2} \mathrm{CO}_{3}(2.76 \mathrm{~g}, 0.02 \mathrm{~mole})$ and tetrabutyl- $n$-ammonium bromide $(0.64 \mathrm{~g}, 0.002 \mathrm{~mol})$. The excess solvent was evaporated and the reaction mixture was poured into water. The separated solid was filtered off, dried and recrystallized from the suitable solvent to give compounds (15-17)a,b.

Ethyl 2-Oxo-5-(2-oxo-2H-chromen-3-yl)-3,4-dihydro-2H-pyran-3-carboxylate (15a). Brown crystals; yield $(2.12 \mathrm{~g}, 67.8 \%) ; \mathrm{m} . \mathrm{p} .>300{ }^{\circ} \mathrm{C}$; acetic acid/water (2:1). ${ }^{1} \mathrm{H}-\mathrm{NMR}\left(\mathrm{DMSO}-\mathrm{d}_{6}\right) \delta: 0.93\left(\mathrm{t}, 3 \mathrm{H}, \mathrm{CH}_{3}\right)$, 1.22-1.35 (m, 2H, $\left.\mathrm{CH}_{2}\right), 1.50-1.62(\mathrm{~m}, 1 \mathrm{H}, \mathrm{CH}), 3.16-3.18\left(\mathrm{q}, 2 \mathrm{H}, \mathrm{OCH}_{2}\right), 6.50-8.16(\mathrm{~m}, 5 \mathrm{H}, 4 \mathrm{ArH},=\mathrm{CH})$, $8.59\left(\mathrm{~s}, 1 \mathrm{H}\right.$, coumarin). IR $(\mathrm{KBr}) \mathrm{cm}^{-1} 1715(\mathrm{C}=\mathrm{O})$. Anal. Calcd. for $\mathrm{C}_{17} \mathrm{H}_{14} \mathrm{O}_{6}: \mathrm{C}, 64.97 ; \mathrm{H}, 4.49$. Found: C, 64.90; H, 4.47.

Ethyl 2-Oxo-5-(3-oxo-3H-benzo[f]chromen-2-yl)-3,4-dihydro-2H-pyran-3-carboxylate (15b). Brown crystals; yield $(2.35 \mathrm{~g}, 64.8 \%)$; m.p. $>300{ }^{\circ} \mathrm{C}$; toluene. ${ }^{1} \mathrm{H}-\mathrm{NMR}\left(\mathrm{DMSO}-d_{6}\right) \delta: 0.93\left(\mathrm{t}, 3 \mathrm{H}, \mathrm{CH}_{3}, J=7.5 \mathrm{~Hz}\right)$, 1.23-1.34 (m, 2H, $\left.\mathrm{CH}_{2}\right), 1.50-1.63(\mathrm{~m}, 1 \mathrm{H}, \mathrm{CH}), 3.10-3.18\left(\mathrm{q}, 2 \mathrm{H}, \mathrm{OCH}_{2}, J=7.5 \mathrm{~Hz}\right), 7.15(\mathrm{t}, 1 \mathrm{H},=\mathrm{CH})$, 7.12-8.08 (m, 6H, ArH), 8.53 (s, $1 \mathrm{H}$, coumarin). IR (KBr) cm ${ }^{-1} 1716$, broad $1625(\mathrm{C}=\mathrm{O})$. Anal. Calcd. for $\mathrm{C}_{21} \mathrm{H}_{16} \mathrm{O}_{6}$ : $\mathrm{C}, 69.23 ; \mathrm{H}, 4.43$. Found: $\mathrm{C}, 69.25 ; \mathrm{H}, 4.41$.

Ethyl 2-amino-6-(2-oxo-2H-chromen-3-yl)-4H-pyran-3-carboxylate (16a). Brown crystals; yield (2.31 g, 74\%); m.p. > $300{ }^{\circ} \mathrm{C}$; ethanol/toluene (2:1). ${ }^{1} \mathrm{H}-\mathrm{NMR}$ (DMSO- $\left.d_{6}\right) \delta: 1.05\left(\mathrm{t}, 3 \mathrm{H}, \mathrm{CH}_{3}, J=7.2 \mathrm{~Hz}\right.$ ), 2.72-2.74 (m, 2H, $\left.\mathrm{CH}_{2}\right), 3.14-3.18(\mathrm{q}, 2 \mathrm{H}, \mathrm{OCH} 2, J=7.2 \mathrm{~Hz}), 4.00\left(\mathrm{~s}, 2 \mathrm{H}, \mathrm{NH}_{2}, \mathrm{D}_{2} \mathrm{O}\right.$ exchangeable), 6.96-7.90 (m, 6H, 4ArH, =CH, CH coumarin). IR (KBr) cm ${ }^{-1}$ : 3418, $3228\left(\mathrm{NH}_{2}\right), 1712(\mathrm{C}=\mathrm{O})$. Anal. Calcd. for $\mathrm{C}_{17} \mathrm{H}_{15} \mathrm{NO}_{5}$ : $\mathrm{C}, 65.17 ; \mathrm{H}, 4.83 ; \mathrm{N}, 4.47$. Found: $\mathrm{C}, 65.10 ; \mathrm{H}, 4.81 ; \mathrm{N}, 4.48$.

Ethyl 2-Amino-6-(3-oxo-3H-benzo[f]chromen-2-yl)-4H-pyran-3-carboxylate (16b). Brown crystals; yield $(2.61 \mathrm{~g}, 72 \%) ;$ m.p. $>300{ }^{\circ} \mathrm{C}$; acetic acid/water (2:1). ${ }^{1} \mathrm{H}-\mathrm{NMR}$ (DMSO- $\left.d_{6}\right) \delta: 0.92\left(\mathrm{t}, 3 \mathrm{H}, \mathrm{CH}_{3}\right.$, $J=7.2 \mathrm{~Hz}), 1.23-1.33\left(\mathrm{~m}, 2 \mathrm{H}, \mathrm{CH}_{2}\right), 2.57\left(\mathrm{~s}, 2 \mathrm{H}, \mathrm{NH}_{2}, \mathrm{D}_{2} \mathrm{O}\right.$ exchangeable), 3.12-3.18 (q, 2H, $\mathrm{OCH}_{2}$, $J=7.2 \mathrm{~Hz}), 6.58(\mathrm{t}, 1 \mathrm{H},=\mathrm{CH}), 7.00-8.50(\mathrm{~m}, 6 \mathrm{H}, \mathrm{ArH}), 8.95\left(\mathrm{~s}, 1 \mathrm{H}\right.$, coumarin). IR $(\mathrm{KBr}) \mathrm{cm}^{-1}: 3409,3242$ $\left(\mathrm{NH}_{2}\right), 1712(\mathrm{C}=\mathrm{O})$. Anal. Calcd. for $\mathrm{C}_{21} \mathrm{H}_{17} \mathrm{NO}_{5}: \mathrm{C}, 69.41 ; \mathrm{H}, 4.72 ; \mathrm{N}, 3.85$. Found: $\mathrm{C}, 69.46 ; \mathrm{H}, 4.71$; $\mathrm{N}, 3.86$.

2-(Dicyanomethyl)-4-oxo-4-(2-Oxo-2H-chromen-3-yl)butanoic Acid (17a). Brown crystals; yield (2.41 g, 78\%); m.p. $>300{ }^{\circ} \mathrm{C}$; ethanol. ${ }^{1} \mathrm{H}-\mathrm{NMR}$ (DMSO- $\left.d_{6}\right) \delta: 2.24-2.28(\mathrm{~m}, 1 \mathrm{H}, \mathrm{CH}), 2.72-2.76\left(\mathrm{~m}, 2 \mathrm{H}, \mathrm{CH}_{2}\right)$, 2.83-2.88 (m, 1H, CH), 7.41-8.44 (m, $4 \mathrm{H}, \mathrm{ArH}), 8.56\left(\mathrm{~s}, 1 \mathrm{H}\right.$, coumarin), $12.22\left(\mathrm{~s}, 1 \mathrm{H}, \mathrm{OH}, \mathrm{D}_{2} \mathrm{O}\right.$ exchangeable). IR $(\mathrm{KBr}) \mathrm{cm}^{-1}$ : $3434(\mathrm{OH}), 2209(\mathrm{C} \equiv \mathrm{N}), 1708,1646(\mathrm{C}=\mathrm{O})$. Anal. Calcd. for $\mathrm{C}_{16} \mathrm{H}_{10} \mathrm{~N}_{2} \mathrm{O}_{5}$ : C, 61.94; H, 3.25; N, 9.03. Found: C, 61.99; H, 3.24; N, 9.13.

2-(Dicyanomethyl)-4-oxo-4-(3-oxo-3H-benzo[f]chromen-2-yl)butanoic Acid (17b). Brown crystals; yield (2.59 g, 72.2\%); m.p. > $300{ }^{\circ} \mathrm{C}$; DMF. ${ }^{1} \mathrm{H}-\mathrm{NMR}$ (DMSO- $\left.d_{6}\right)$ ): 2.63-2.67 (m, 1H, CH), 2.72-2.79 (m, 2H, $\left.\mathrm{CH}_{2}\right), 2.88-2.91(\mathrm{~m}, 1 \mathrm{H}, \mathrm{CH}), 7.04-8.64(\mathrm{~m}, 4 \mathrm{H}, \mathrm{ArH}), 8.93(\mathrm{~s}, 1 \mathrm{H}$, coumarin), $12.56(\mathrm{~s}, 1 \mathrm{H}, \mathrm{OH}$, $\mathrm{D}_{2} \mathrm{O}$ exchangeable). IR $(\mathrm{KBr}) \mathrm{cm}^{-1}: 3434(\mathrm{OH}), 2210(\mathrm{C} \equiv \mathrm{N}), 1713,1632(\mathrm{C}=\mathrm{O})$. Anal. Calcd. for $\mathrm{C}_{20} \mathrm{H}_{12} \mathrm{~N}_{2} \mathrm{O}_{5}: \mathrm{C}, 66.67 ; \mathrm{H}, 3.36 ; \mathrm{N}, 7.77$. Found: $\mathrm{C}, 66.64 ; \mathrm{H}, 3.37 ; \mathrm{N}, 7.79$. 


\subsubsection{General Procedure for the Synthesis of Compounds 18a and 18b}

A mixture of compounds 17a,b $(3.10 \mathrm{~g}, 0.01 \mathrm{~mol})$, hydrazine hydrate $(0.50 \mathrm{~mL}, 0.01 \mathrm{~mol})$ in DMF $(20 \mathrm{~mL})$ was refluxed for $3 \mathrm{~h}$, cool, poured on water, The solid that separated was filtered off, dried and recrystallized from the proper solvent to give compounds $\mathbf{1 8 a}$ and $\mathbf{1 8 b}$ respectively.

2-(3-Oxo-6-(2-oxo-2H-chromen-3-yl)-2,3,4,5-tetrahydropyridazin-4-yl)malononitrile (18a). Brown crystals; yield $\left(2.40\right.$ g, 83\%); m.p. $>300{ }^{\circ} \mathrm{C}$; AcOH $/ \mathrm{H}_{2} \mathrm{O}(3: 1) .{ }^{1} \mathrm{H}-\mathrm{NMR}$ (DMSO- $\left.d_{6}\right) \delta: 1.23-1.27(\mathrm{~m}, 1 \mathrm{H}, \mathrm{CH})$, 1.90-1.95 (m, 2H, $\left.\mathrm{CH}_{2}\right), 2.71(\mathrm{~d}, 1 \mathrm{H}, \mathrm{CH}), 6.50-8.00(\mathrm{~m}, 4 \mathrm{H}, \mathrm{ArH}), 8.13(\mathrm{~s}, 1 \mathrm{H}$, coumarin), $8.60(\mathrm{~s}$, $1 \mathrm{H}, \mathrm{NH}, \mathrm{D}_{2} \mathrm{O}$ exchangeable). IR $(\mathrm{KBr}) \mathrm{cm}^{-1}: 3362(\mathrm{NH}), 2211(\mathrm{C} \equiv \mathrm{N}), 1627(\mathrm{C}=\mathrm{O})$. Anal. Calcd. for $\mathrm{C}_{16} \mathrm{H}_{10} \mathrm{~N}_{4} \mathrm{O}_{3}$ : C, 62.74; H, 3.29; N, 18.29. Found: $\mathrm{C}, 62.75 ; \mathrm{H}, 3.27 ; \mathrm{N}, 18.28$.

2-(3-Oxo-6-(3-oxo-3H-benzo[f]chromen-2-yl)-2,3,4,5-tetrahydropyridazin-4-yl)malononitrile (18b). Brown crystals; yield (2.70 g, 79.6\%); m.p. $>300{ }^{\circ} \mathrm{C}$; DMF. ${ }^{1} \mathrm{H}-\mathrm{NMR}$ (DMSO-d $\left.{ }_{6}\right) \delta: 1.20-1.22(\mathrm{~m}, 1 \mathrm{H}, \mathrm{CH})$, 1.92-1.97 (m, 2H, $\left.\mathrm{CH}_{2}\right), 2.21(\mathrm{~d}, 1 \mathrm{H}, \mathrm{CH}), 6.56-8.25(\mathrm{~m}, 6 \mathrm{H}, \mathrm{ArH}), 8.13(\mathrm{~s}, 1 \mathrm{H}$, coumarin), $8.54(\mathrm{~s}$, $1 \mathrm{H}, \mathrm{NH}, \mathrm{D}_{2} \mathrm{O}$ exchangeable). IR $(\mathrm{KBr}) \mathrm{cm}^{-1}: 3399(\mathrm{NH}), 2207(\mathrm{C} \equiv \mathrm{N}), 1627(\mathrm{C}=\mathrm{O})$. Anal. Calcd. for $\mathrm{C}_{20} \mathrm{H}_{12} \mathrm{~N}_{4} \mathrm{O}_{3}$ : C, 67.41; H, 3.39; N, 15.72. Found: $\mathrm{C}, 67.42 ; \mathrm{H}, 3.38 ; \mathrm{N}, 15.73$.

3.2.11. Synthesis of 2-(6-Oxo-3-(2-oxo-2H-chromen-3-yl)-5,6-dihydro-4H-1,2-oxazin-5-yl) malon-onitrile 19

A mixture of compound 17 ( $3.10 \mathrm{~g}, 0.01 \mathrm{~mol})$, and hydroxylamine hydrochloride $(0.69 \mathrm{~g}, 0.01 \mathrm{~mol})$ in pyridine $(20 \mathrm{~mL})$ was refluxed for $3 \mathrm{~h}$, cool, poured onto ice/ $\mathrm{HCl}$, The solid that separated was filtered off, dried and recrystallized from ethanol/benzene to give compound $\mathbf{1 9}$ as brown crystals; yield $\left(2.01 \mathrm{~g}\right.$, 65.5\%); m.p. $>300{ }^{\circ} \mathrm{C}$; ethanol/benzene (2:1). ${ }^{1} \mathrm{H}-\mathrm{NMR}$ (DMSO- $\left.d_{6}\right) \delta: 1.22-1.25$ (d, $\left.2 \mathrm{H}, \mathrm{CH}_{2}\right), 2.26-2.30(\mathrm{~m}, 1 \mathrm{H}, \mathrm{CH}), 2.72(\mathrm{~d}, 1 \mathrm{H}, \mathrm{CH}), 7.05-8.34(\mathrm{~m}, 4 \mathrm{H}, \mathrm{ArH}), 8.77$ (s, 1H, coumarin). IR $(\mathrm{KBr}) \mathrm{cm}^{-1}: 2209(\mathrm{C} \equiv \mathrm{N}), 1713,1627(\mathrm{C}=\mathrm{O})$. Anal. Calcd. for $\mathrm{C}_{16} \mathrm{H}_{9} \mathrm{~N}_{3} \mathrm{O}_{4}: \mathrm{C}, 62.54 ; \mathrm{H}, 2.95 ; \mathrm{N}, 13.68$; Found: C, 62.51; H, 2.93; N, 13.66 .

\subsection{Pharmacological Activity}

\subsubsection{Cytotoxicity Assay}

The cytotoxic activity of twenty two compounds was tested against four human tumor cell lines namely: hepatocellular carcinoma (liver) HePG2, colon cancer HCT-116, human (prostate) cancer PC3 and mammary gland (breast) MCF-7. The cell lines were obtained from ATCC via the Holding company for biological products and vaccines (VACSERA, Cairo, Egypt). 5-Fluorouracil was used as a standard anticancer drug for comparison. The reagents used were RPMI-1640 medium, MTT, DMSO and 5-fluorouracil (Sigma Co., St. Louis, MO, USA), and fetal bovine serum (GIBCO, Paisely, UK).

\section{MTT Assay}

The different cell lines $[54,55]$ mentioned above were used to determine the inhibitory effects of compounds on cell growth using the MTT assay. This colorimetric assay is based on the conversion of the yellow tetrazolium bromide (MTT) to a purple formazan derivative by mitochondrial succinate dehydrogenase in viable cells. The cells were cultured in RPMI- 1640 medium with $10 \%$ fetal bovine serum. Antibiotics added were 100 units $/ \mathrm{mL}$ penicillin and $100 \mu \mathrm{g} / \mathrm{mL}$ streptomycin at $37{ }^{\circ} \mathrm{C}$ in a $5 \% \mathrm{CO}_{2}$ incubator. The cells lines were seeded [56] in a 96-well plate at a density of $1.0 \times 10^{4}$ cells/well at $37^{\circ} \mathrm{C}$ for $48 \mathrm{~h}$ under $5 \% \mathrm{CO}_{2}$. After incubation the cells were treated with different concentration of compounds and incubated for $24 \mathrm{~h}$. After $24 \mathrm{~h}$ of drug treatment, $20 \mu \mathrm{L}$ of MTT solution at $5 \mathrm{mg} / \mathrm{mL}$ was added and incubated for $4 \mathrm{~h}$. Dimethyl sulfoxide (DMSO) in volume of $100 \mu \mathrm{L}$ is added into each well to dissolve the purple formazan formed. The colorimetric assay is measured and recorded at absorbance of $570 \mathrm{~nm}$ using a plate reader (EXL 800, BioTech, Winooski, 
VT, USA). The relative cell viability in percentage was calculated as $\left(A_{570}\right.$ of treated samples $/ A_{570}$ of untreated sample) $\times 100$.

\subsubsection{Antioxidant Assay}

\section{ABTS Method}

For each of the investigated compounds [57-59] of ABTS solution $(60 \mu \mathrm{M}, 2 \mathrm{~mL})$ was added to $\mathrm{MnO}_{2}$ suspension $(25 \mathrm{mg} / \mathrm{mL}, 3 \mathrm{~mL})$, all prepared in aqueous phosphate buffer solution ( $\mathrm{pH} 7,0.1 \mathrm{M}$, $5 \mathrm{~mL}$ ). The mixture was shaken, centrifuged, filtered and the absorbance of the resulting green blue solution (ABTS radical solution) at $734 \mathrm{~nm}$ was adjusted to approx. ca. 0.5. Then, asolution (50 $\mu \mathrm{L}$ of $(2 \mathrm{mM})$ of the tested compound in spectroscopic grade $\mathrm{MeOH} /$ phosphate buffer (1:1) was added. The absorbance was measured and the reduction in color intensity was expressed as inhibition percentage. L-ascorbic acid was used as standard antioxidant (positive control). Blank sample was run without ABTS and using $\mathrm{MeOH} /$ phosphate buffer (1:1) instead of the tested compounds. Negative control was run with $\mathrm{ABTS}$ and $\mathrm{MeOH} /$ phosphate buffer (1:1) only.

Bleomycin—Dependent DNA Damage Assay

To the reaction mixtures $[60,61]$ in a final volume of $1.0 \mathrm{~mL}$, the following reagents were added: DNA $(0.2 \mathrm{mg} / \mathrm{mL})$, bleomycin sulfate $(0.05 \mathrm{mg} / \mathrm{mL}), \mathrm{FeCl}_{3}(0.025 \mathrm{mM})$, magnesium chloride $(5 \mathrm{mM})$, $\mathrm{KH}_{2} \mathrm{PO}_{4--} \mathrm{KOH}$ buffer $\mathrm{pH} 7.0(30 \mathrm{mM})$, and ascorbic acid $(0.24 \mathrm{mM})$ or the test fractions diluted in $\mathrm{MeOH}$ to give a concentration of $(0.1 \mathrm{mg} / \mathrm{mL})$. The reaction mixtures were incubated in a water bath at $37^{\circ} \mathrm{C}$ for $1 \mathrm{~h}$. At the end of the incubation period, $0.1 \mathrm{~mL}$ of ethylenediaminetetraacetic acid (EDTA) (0.1 M) was added to stop the reaction (the iron-EDTA complex is unreactive in the bleomycin assay). DNA damage was assessed by adding $1 \mathrm{~mL} 1 \%(w / v)$ thiobarbituric acid (TBA) and $1 \mathrm{~mL}$ of $25 \%(v / v)$ hydrochloric acid followed by heating in a water-bath maintained at $80{ }^{\circ} \mathrm{C}$ for $15 \mathrm{~min}$. The chromogenic formed was extracted into 1-butanol, and the absorbance was measured at $532 \mathrm{~nm}$.

\section{Conclusions}

The objective of the present study was to synthesize the coumarin scaffold-based compounds and evaluate their cytotoxicity, antioxidant and bleomycin dependent DNA damage protection activities. The tested compounds showed very strong to non-cytotoxic activity against four anticancer cell lines. The best results were observed for compounds $5 \mathbf{a}, \mathbf{7 a}, \mathbf{b}, \mathbf{9 a}, \mathbf{b}, \mathbf{1 3} \mathbf{b}, \mathbf{1 5} \mathbf{a}, \mathbf{b}, \mathbf{1 6} \mathbf{a}$ and $\mathbf{1 8 a}$. Compound $\mathbf{1 5 b}$ showed activity approximately equal to that of 5-FU as a standard against PC 3 and compound $\mathbf{7 b}$ showed higher activity than the 5-FU against HCT-116.

Supplementary Materials: Supplementary materials can be accessed at: http:/ /www.mdpi.com/1420-3049/21/ 2/249/s1.

Acknowledgments: Technical support from Department of Chemistry, Faculty of Science, Ain Shams University is gratefully acknowledged.

Author Contributions: The authors contributed equally to this work.

Conflicts of Interest: The authors declare no conflict of interest.

\section{References}

1. Musa, M.A.; Badisa, V.L.; Latinwo, L.M.; Cooperwood, J.; Sinclair, A.; Abdullah, A. Cytotoxic activity of new acetoxycoumarin derivatives in cancer cell lines. Anticancer Res. 2011, 31, 2017-2022. [PubMed]

2. Borah, P.; Naidu, P.S.; Bhuyan, P.J. Synthesis of some tetrazole fused pyrido[2,3-c]coumarin derivatives from a one-pot three-component reaction via intramolecular 1,3-dipolar cycloaddition reaction of azide to nitriles. Tetrahedron Lett. 2012, 53, 5034-5037. [CrossRef]

3. El-Ansary, S.L.; Abbas, S.E.; Mikhael, A.N.; El-Banna, H.A. Synthesis and biological activity of some new coumarins. Egypt. J. Pharm. Sci. 1992, 33, 639-650. 
4. Manfredini, S.; Daniele, S.; Ferroni, R.; Bazzanini, R.; Vertuani, S.; Hatse, S.; Balzarini, J.; de Clercq, E. retinoic acid conjugates as potential antitumor agents: synthesis and biological activity of conjugates with Ara-A, Ara-C, 3(2H)-furanone, and aniline mustard moieties. J. Med. Chem. 1997, 40, 3851-3857. [CrossRef] [PubMed]

5. Wattenberg, L.W.; Lam, K.T.; Fladmoe, A.V. Inhibition of chemical carcinogen-induced neoplasia by coumarins and $\alpha$-angelicalactone. Cancer Res. 1979, 39, 1651-1654. [PubMed]

6. Kashman, Y.; Gustafson, K.R.; fuller, R.W.; Cardellina, J.H.; McMahon, J.B.; Currens, M.J.; Buckheit, R.W.; Hughes, S.H.; Craqq, G.M.; Boyd, M.R. The calanolides, a novel HIV-inhibitory class of coumarin derivatives from the tropical rainforest tree, Calophyllum lanigerum. J. Med. Chem. 1992, 35, 2735-2743. [CrossRef] [PubMed]

7. Mckee, T.C.; Fuller, R.W.; Covington, C.D.; Cardellina, J.H.; Gulakowski, R.J.; Krepps, B.L.; McMahon, J.B.; Boyd, M.R. New pyranocoumarins isolated from Calophyllum lanigerum and Calophyllum teysmannii. J. Nat. Prod. 1996, 59, 754-758.

8. Anjum, N.F.; Aleem, A.; Nayeem, N.; Asdaq, S.M. Synthesis and antibacterial activity of substituted 2-phenyl-4-chromones. Der Pharma Chem. 2011, 3, 56-62.

9. De Souza, S.M.; Delle Monache, F.; Smânia, A., Jr. Antibacterial activity of coumarins. Z. Naturforsch. C 2005, 60, 693-700. [CrossRef] [PubMed]

10. Behrami, A. Antibacterial activity of coumarine derivatives synthesized from 4-chloro-chromen-2-one. The comparison with standard drug. Orient. J. Chem. 2014, 30, 1747-1752. [CrossRef]

11. Jung, J.; Kim, J.; Park, O. Simple and cost effective syntheses of 4-hydroxycoumarin. Synth. Commun. 1999, 29, 3587-3595. [CrossRef]

12. Barker, W.M.; Hermodson, M.A.; Link, K.P. 4-Hydroxycoumarins. Synthesis of the metabolites and some other derivatives of warfarin. J. Med. Chem. 1971, 14, 167-169. [CrossRef]

13. Greaves, M. Pharmacogenetics in the management of coumarin anticoagulant therapy: The way forward or an expensive diversion? PLoS Med. 2005, 2, e342. [CrossRef] [PubMed]

14. Montagner, C.; de Souzaa, S.M.; Groposo, C.; Delle Monacheb, F.; Smânia, E.F.A.; Smâ^nia, A., Jr. Antifungal activity of coumarins. Z. Naturforsch. C 2008, 63, 21-28. [CrossRef] [PubMed]

15. De Araújo, R.S.A.; Guerra, F.Q.S.; Lima, E.; De Simone, C.A.; Tavares, J.F.; Scotti, L.; Scotti, M.T.; De Aquino, T.M.; De Moura, R.O.; Mendonça, F.J.B.; et al. Synthesis, structure-activity relationships (SAR) and in silico studies of coumarin derivatives with antifungal activity. Int. J. Mol. Sci. 2013, 14, 1293-1309. [CrossRef] [PubMed]

16. Mazzone, G.; Malaj, N.; Galano, A.; Russo, N.; Toscano, M. Antioxidant properties of several coumarin-chalcone hybrids from theoretical insights. RSC Adv. 2015, 5, 565-575. [CrossRef]

17. Raboin, J.; Beley, M.; Kirsch, G. Pyridine-fused coumarins: A new class of ligands for ruthenium complexes with enhanced spectral absorption. Tetrahedron Lett. 2000, 4, 1175-1177. [CrossRef]

18. Karatzas, N.B. Coumarins, a class of drugs with a unique contribution to medicine: The tale of their discovery. Hellenic J. Cardiol. 2014, 55, 89-91. [PubMed]

19. Agarwal, R. Synthesis and biological screening of some novel coumarin derivatives. Biochem. Pharmacol. 2000, 6, 1042-1051.

20. Marshall, M.E.; Butler, K.; Hermansen, D. Treatment of hormone-refractory stage D carcinoma of prostate with coumarin (1,2-benzopyrone) and cimetidine: A pilot study. Prostate 1990, 17, 95-99. [CrossRef] [PubMed]

21. Benci, K.; Mandić, L.; Suhina, T.; Sedić, M.; Klobučar, M.; Pavelić, S.K.; Pavelić, K.; Wittine, K.; Mintas, M. Novel coumarin derivatives containing 1,2,4-triazole, 4,5-dicyanoimidazole and purine moieties: Synthesis and evaluation of their cytostatic activity. Molecules 2012, 17, 11010-11025. [CrossRef] [PubMed]

22. Marshall, M.E.; Kervin, K.; Benefield, C.; Umerani, A.; Albainy-Jenei, S.; Zhao, Q.; Khazaeli, M.B. Growth-inhibitory effects of coumarin (1,2-benzopyrone) and 7-hydroxycoumarin on human malignant cell lines in vitro. J. Cancer Res. Clin. Oncol. 1994, 120, S3-S10. [CrossRef] [PubMed]

23. Mohler, J.L.; Gomella, L.G.; Crawford, E.D.; Glode, L.M.; Zippe, C.D.; Fair, W.R.; Marshall, M.E. Phase II evaluation of coumarin (1,2-benzopyrone) in metastatic prostatic carcinoma. Prostate 1992, 20, 123-131. [CrossRef] [PubMed] 
24. Thornes, R.D.; Daly, L.; Lynch, G.; Breslin, B.; Browne, H.; Browne, H.Y.; Corrigan, T.; Daly, P.; Edwards, G.; Gaffney, E.; et al. Treatment with coumarin to prevent or delay recurrence of malignant melanoma. J. Cancer Res. Clin. Oncol. 1994, 120, S32-S34. [CrossRef] [PubMed]

25. Marshall, M.E.; Butler, K.; Fried, A. Phase I evaluation of coumarin (1,2-benzopyrone) and cimetidine in patients with advanced malignancies. Mol. Biother. 1991, 3, 170-178. [PubMed]

26. Mirunalini, S.; Deepalakshmi, K.; Manimozhi, J. Antiproliferative effect of coumarin by modulating oxidant/antioxidant status and inducing apoptosis in Hep2 cells. Biomed. Aging Pathol. 2014, 4, 131-135. [CrossRef]

27. Sashidhara, K.V.; Avula, S.R.; Sharma, K.; Palnati, G.R.; Bathula, S.R. Discovery of coumarin monastrol hybrid as potential antibreast tumor-specific agent. Eur. J. Med. Chem. 2013, 60, 120-127. [CrossRef] [PubMed]

28. Jamier, V.; Marut, W.; Valente, S.; Chereau, C.; Chouzenoux, S.; Nicco, C.; Lemarechal, H.; Weill, B.; Kirsch, G.; Jacob, C.; et al. Chalcone-coumarin derivatives as potential anticancer drugs: An in vitro and in vivo investigation. Anticancer Agents Med. Chem. 2014, 14, 963-974. [CrossRef] [PubMed]

29. Seidel, C.; Schnekenburger, M.; Zwergel, C.; Gaascht, F.; Mai, A.; Dicato, M.; Kirsch, G.; Valente, S.; Diederich, M. Novel inhibitors of human histone deacetylases: Design, synthesis and bioactivity of 3-alkenoylcoumarines. Bioorg. Med. Chem. Lett. 2014, 24, 3797-3801. [CrossRef] [PubMed]

30. Kim, W.J.; Lee, S.J.; Choi, Y.D.; Moon, S.K. Decursin inhibits growth of human bladder and colon cancer cells via apoptosis, G1-phase cell cycle arrest and extracellular signal-regulated kinase activation. Int. J. Mol. Med. 2010, 25, 635-641. [PubMed]

31. Amin, K.M.; Abou-Seri, S.M.; Awadallah, F.M.; Eissa, A.A.M.; Hassan, G.S.; Abdulla, M.M. Synthesis and anticancer activity of some 8-substituted-7-methoxy-2H chromen-2-one derivatives toward hepatocellular carcinoma HepG2 cells. Eur. J. Med. Chem. 2015, 90, 221-231. [CrossRef] [PubMed]

32. Migawa, M.T.; Drach, J.C.; Townsend, L.B. Design, synthesis and antiviral activity of novel 4,5-disubstituted 7-( $\beta$-D-Ribofuranosyl)pyrrolo[2,3- $d][1,2,3]$ triazines and the novel 3-amino-5-methyl-1-( $\beta$-D-ribofuranosyl)and 3-amino-5-methyl-1-(2-deoxy- $\beta$-D-ribofuranosyl)-1,5-dihydro-1,4,5,6,7,8-hexaazaace-naphthylene as an-alogues of triciribine. J. Med. Chem. 2005, 48, 3840-3851. [PubMed]

33. El-Kasaby, M.A.; Salem, M.A.I. Synthesis and reactions of 6,7(4'-alkyl- $\alpha$-pyrano)-4-alkyl coumarin. Rev. Roum. Chem. 1981, 26, 717-723.

34. Salem, M.A.I.; El-Kasaby, M.A. Reaction of 3-carbethoxy-5,6-benzocoumarin with anthranilic acid, synthesis and some reactions. J. Chem. Soc. Pak. 1987, 19, 177-189.

35. Abdou, W.M.; Salem, M.A.I.; Sediek, A.A. The reactivity of 2-acetyl(3H)naphtha[2,1-b]pyran-3-one, synthesis of coummarinyl[2,1-b]fused cyclic compounds. Heterocycl. Commun. 1998, 4, 145-150. [CrossRef]

36. Marzouk, M.I. Study on 2-Cyanobenzo[f]chromen-3-one as Michael acceptors. Int. J. Chem. 2002, 12, 1-7.

37. Nofal, Z.M.; EL-Zahar, M.I.; Salem, M.A.I.; Madkour, H.M.F.; Abd EL-Karim, S.S. Synthesis and chemophylatic effect of novel coumarin derivatives. Egypt. J. Chem. 2005, 48, 587-704.

38. Tolstoluzhsky, N.V.; Gorobets, N.Y.; Kolos, N.N.; Desenko, S.M. Efficient ytterbium triflate catalyzed microwave-assisted synthesis of 3-acylacrylic acid building blocks. J. Comb. Chem. 2008, 10, 893-896. [CrossRef] [PubMed]

39. El-Hashash, M.A.; Rizk, S.A.; Atta-Allah, S.R. Synthesis and regioselective reaction of some unsymmetrical heterocyclic chalcone derivatives and spiro heterocyclic compounds as antibacterial agents. Molecules 2015, 20, 22069-22083. [CrossRef] [PubMed]

40. Sharshira, E.M.; Hamada, N.M.M. Synthesis, antibacterial and antifungal activities of some pyrazole-1-carbothioamides and pyrimidine-2(1H)-thiones. Am. J. Org. Chem. 2012, 2, 26-31. [CrossRef]

41. Salem, M.S.; Marzouk, M.I.; Ali, S.N.; Madkour, H.M.F. Synthesis, structure characterization and biological evaluation of new 6,8-dichloro-2-methyl-4H-chromen-4-one derivatives. Eur. J. Chem. 2012, 3, 220-227. [CrossRef]

42. Dotsenko, V.V.; Krivokolysko, S.G.; Litvinov, B.P. Reaction of diketene with cyanothioacetamide: A convenient and regioselective method for the preparation of new 4(1H)-pyridone derivatives. Chem. Heterocycl. Compd. 2007, 43, 599-607. [CrossRef]

43. Minetto, G.; Raveglia, L.F.; Sega, A.; Taddei, M. Microwave-assisted Paal-Knorr reaction-three-step Regio controlled synthesis of polysubstituted furans, pyrroles and thiophenes. Eur. J. Org. Chem. 2005, 2005, 5277-5288. [CrossRef] 
44. Dere, R.T.; Pal, R.R.; Patil, P.S.; Salunkhe, M.M. Influence of ionic liquids on the phase transfer-catalysed enantioselective Michael reaction. Tetrahedron Lett. 2003, 44, 5351-5353. [CrossRef]

45. Zhang, Z.; Dong, Y.-W.; Wang, G.-W.; Komatsu, K. Highly efficient mechanochemical reactions of 1,3-dicarbonyl compounds with chalcones and azachalcones catalyzed by potassium carbonate. Synlett 2004, 1, 61-64. [CrossRef]

46. Salem, M.S.; Guirguis, D.B.; El-Helw, E.A.E.; Ghareeb, M.A.; Derbala, H.A.Y. Antioxidant activity of heterocyclic compounds derived from 4-(4-acetamidophenyl)-4-oxobut-2-enoic acid. Int. J. Sci. Res. 2014, 3, 1274-1282.

47. Gutteridge, J.M.; Rowley, D.A.; Halliwell, B. Superoxide-dependent formation of hydroxyl radicals in the presence of iron salts. Detection of "free" iron in biological systems by using bleomycin-dependent degradation of DNA. Biochem. J. 1981, 199, 263-265. [CrossRef] [PubMed]

48. Singh, K.R.; Lange, S.T.; Kim, K.K.; Brard, L. A coumarin derivative (RKS262) inhibits cell-cycle progression, causes pro-apoptotic signaling and cytotoxicity in ovarian cancer cells. Investig. New Drugs 2011, 29, 63-72. [CrossRef] [PubMed]

49. Wang, J.; Lu, M.L.; Dai, H.L.; Zhang, S.P.; Wang, H.X.; Wei, N. Esculetin, a coumarin derivative, exerts in vitro and in vivo antiproliferative activity against hepatocellular carcinoma by initiating a mitochondrial-dependent apoptosis pathway. Braz. J. Med. Biol. Res. 2015, 48, 245-253. [CrossRef] [PubMed]

50. Zhang, W.; Li, Z.; Zhou, M.; Wu, F.; Hou, X.; Luo, H.; Liu, H.; Han, X.; Yan, G.; Ding, Z.; et al. Synthesis and biological evaluation of 4-(1,2,3-triazol-1-yl)coumarin derivatives as potential antitumor agents. Bioorg. Med. Chem. Lett. 2014, 24, 799-807. [CrossRef] [PubMed]

51. Amin, K.M.; Eissa, A.M.; Abou-Seri, S.M.; Awadallah, F.M.; Hassan, G.S. Synthesis and biological evaluation of novel coumarin-pyrazoline hybrids endowed with phenylsulfonyl moiety as antitumor agents. Eur. J. Med. Chem. 2013, 60, 187-198. [CrossRef] [PubMed]

52. Nasr, T.; Bondock, S.; Youns, M. Anticancer activity of new coumarin substituted hydrazide-hydrazone derivatives. Eur. J. Med. Chem. 2014, 76, 539-548. [CrossRef] [PubMed]

53. Bohon, J.; Santos, C.R. Structural effect of the anticancer agent 6-thioguanine on duplex DNA. Nucleic Acids Res. 2003, 31, 1331-1338. [CrossRef] [PubMed]

54. Mosmann, T. Rapid colorimetric assay for cellular growth and survival: Application to proliferation and cytotoxicity assays. J. Immunol. Methods 1983, 65, 55-63. [CrossRef]

55. Denizot, F.; Lang, R. Rapid colorimetric assay for cell growth and survival. Modifications to the tetrazolium dye procedure giving improved sensitivity and reliability. J. Immunol. Methods 1986, 89, 271-277. [CrossRef]

56. Mauceri, H.J.; Hanna, N.N.; Beckett, M.A.; Gorski, D.H.; Staba, M.; Stellato, K.A.; Bigelow, K.; Heimann, R.; Gately, S.; Dhanabal, M.; et al. Combined effects of angiostatin and ionizing radiation in antitumour therapy. Nature 1998, 394, 287-291. [PubMed]

57. Lissi, E.A.; Modak, B.; Torres, R.; Escobar, J.; Urzua, A. Total antioxidant potential of resinous exudates from Heliotropium Species and a comparison of ABTS and DPPH methods. Free Radic. Res. 1999, 30, 471-477. [CrossRef] [PubMed]

58. El-Gazar, A.B.A.; Youssef, M.M.; Youssef, A.M.S.; Abu-Hashem, A.A.; Badria, F.A. Design and synthesis of azolopyrimidoquinolines, pyrimidoquinazolines as antioxidant, anti-inflammatory and analgesic activities. Eur. J. Med. Chem. 2009, 44, 609-624. [CrossRef] [PubMed]

59. Aeschbach, R.; Löliger, J.; Scott, B.C.; Murcia, A.; Butler, J.; Halliwell, B.; Aruoma, O.I. Antioxidant actions of thymol, carvacrol, 6-gingerol, zingerone and hydroxytyrosol. Food Chem. Toxicol. 1994, 32, 31-36. [CrossRef]

60. Abdel-Wahab, B.F.; EL-Ahl, A.S.; Badria, F.A. synthesis of new 2-naphthyl ethers and their protective activities against DNA damage induced by bleomycin-iron. Chem. Pharm Bull. 2009, 57, 1348-1351. [CrossRef] [PubMed]

61. Badria, F.A.; Ameen, M.; Akl, M.R. Evaluation of cytotoxic compounds from Calligonum comosum L. growing in Egypt. Z. Naturforsch. C 2007, 62, 656-660. [CrossRef] [PubMed]

Sample Availability: Samples of the compounds are not available from the authors.

(C) 2016 by the authors; licensee MDPI, Basel, Switzerland. This article is an open access article distributed under the terms and conditions of the Creative Commons by Attribution (CC-BY) license (http://creativecommons.org/licenses/by/4.0/). 